\title{
The Late Carboniferous Schönfeld-Altenberg Depression on the NW margin of the Bohemian Massif (Germany/Czech Republic): volcanosedimentary and magmatic evolution
}

\author{
Danilo WALTHER ${ }^{1}$, Christoph BREITKREUZ ${ }^{*}$, Vladislav RAPPRICH², Yulia V. KOCHERGINA², \\ Marta CHLUPÁČOVÁ ${ }^{3}$, Manuel LAPP4, Klaus STANEK ${ }^{1}$, Tomáš MAGNA ${ }^{2}$ \\ ${ }^{1}$ Institut für Geologie, TU Bergakademie Freiberg, Bernhard von Cotta Str. 2, 09599 Freiberg, Germany; \\ Christoph.Breitkreuz@geo.tu-freiberg.de \\ ${ }^{2}$ Czech Geological Survey, Klárov 3, 11821 Prague 1, Czech Republic \\ ${ }^{3}$ Boháčova 866/4, 14900 Prague 4, Czech Republic \\ ${ }^{4}$ Landesamt für Umwelt, Landwirtschaft und Geologie, Postfach 5401 37, 01311 Dresden, Germany \\ * Corresponding author
}

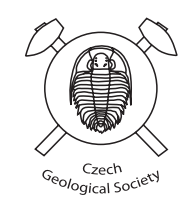

The Altenberg-Teplice Volcanic Complex (ATVC) exposed on both sides of the German-Czech border in the Erzgebirge/ Krušné hory Mts. is one of the earliest late-Variscan to post-Variscan volcanic centres in Europe. The ATVC features an early volcanosedimentary succession preserved in the Schönfeld-Altenberg Depression Complex (SADC), covered by voluminous ignimbrites and lavas of the Teplice Rhyolite (TR). Published radiometric age dating of ATVC rocks and associated mineralizations suggest a Lower Namurian (Serpukhovian) age for the SADC.

The SADC $(10 \times 15 \mathrm{~km})$ was subdivided into the Schönfeld-Pre-Eruptive Sediments (SPES), and the volcanosedimentary successions of the Lower Schönfeld Complex (LSC) and the Upper Schönfeld Complex (USC). The SPES (maximum thickness of $60 \mathrm{~m}$ ) is deposited on metamorphic basement and consists of sandstones and conglomerates with variable types of metamorphic clasts; it also contains carbonaceous layers. The LSC sequence starts with widespread, fine-grained ignimbrites (maximum thickness of $153 \mathrm{~m}$ ) of rhyolitic composition. The explosive phase of the LSC was followed by the formation of (trachy-)dacitic lava(s) and subvolcanic bodies. The USC sequence commences with coarse-grained talus deposits, consisting of metamorphic clasts, indicating a major tectonic activity. Lavas and pyroclastic rocks dominate the USC in the southern part, whereas in the Schönfeld area (northern part), lava dome explosion-related pyroclastic and sedimentary deposits, alternating with carbonaceous layers, prevail.

Charcoal fragments and fine charcoal dust is present in all SADC units as layers, or in the matrix of volcanosedimentary deposits. Allochtonous anthracite seams in the USC that were subject to historic mining in the Schönfeld area consist of a bedded alternation of carbonaceous deposits with clays to siltstones. Presumably, formation of charcoal was related to explosive eruptions and/or wild fires, and redeposition by alluvial processes.

The SADC volcanic rocks are classified as dacites, trachy-dacites and rhyolites, having unusually elevated concentrations of Ti and compatible elements like Cr and V. Compared to the LSC, the USC volcanics show a less alkaline affinity. The studied samples are isotopically homogeneous, with $\varepsilon \mathrm{Nd}_{325}=-2.4$ to -3.3 and ${ }^{87} \mathrm{Sr}^{186} \mathrm{Sr}_{325}=0.70556-0.70626$, pointing to a common source of magmas for both the LSC and the USC. The two-stage Nd model ages vary between 1.2 and $1.3 \mathrm{Ga}$, similar to coeval Saxothuringian granites from the Erzgebirge Mts. as well as volcanic rocks from the Intra-Sudetic Basin.

Keywords: Altenberg-Teplice Volcanic Complex, post-Variscan magmatism, volcanology, dacite, Sr-Nd isotopes, charcoal Received: 8 June, 2016; accepted: 29 November, 2016; handling editor: M. Štemprok

The online version of this article (doi: 10.3190/jgeosci.219) contains supplementary electronic material.

\section{Introduction}

The Laurussia-Gondwana collision has driven the geological processes throughout Central Europe during the Late Paleozoic. In the late Variscan to post-Variscan phase, intense magmatism led to the formation of numerous large intrusive and effusive complexes (Timmerman 2008). In the Erzgebirge/Krušné hory Mts. block, which forms an integral part of the Saxothuringian Zone (Kroner and Romer 2010), magmatic activity as early as Up- per Mississippian is recorded (e.g., intrusive complexes of the Meissen-, Eibenstock-, Niederbobritzsch-, and Fláje plutons). The Tharandt Caldera near Dresden and the Altenberg-Teplice Volcanic Complex (ATVC, Fig. 1) represent products of the oldest late Variscan volcanic activity in the Saxothuringian block. Younger (Late Carboniferous and, in particular, Early Permian) extensive volcanism is known from several inter-montane Variscan basins in Central Europe (e.g., Hoffmann et al. 2013 and references therein). 
The ATVC includes the volcanosedimentary Schönfeld-Altenberg Depression Complex (SADC), covered by the voluminous Teplice Rhyolite (TR) built mainly by welded rhyolitic ignimbrites. The SADC represents the earliest preserved post-Variscan volcanosedimentary complex, and its study has the potential to shed some light on early post-Variscan evolution of the Bohemian Massif. Significant amounts of isolated observations and data on the SADC are disseminated in publications and unpublished reports but a comprehensive study summa- rizing the volcanosedimentary and magmatic evolution of the SADC has been missing so far. The aims of this paper are to (i) provide a synthesis on the SADC based on published and unpublished data accumulated on both sides of the Czech-German border during mapping, exploration and basic research, and (ii) characterize the nature, setting and evolution of the SADC. Furthermore we present and discuss whole-rock geochemical data and $\mathrm{Sr}-\mathrm{Nd}$ isotope ratios of the SADC volcanics.

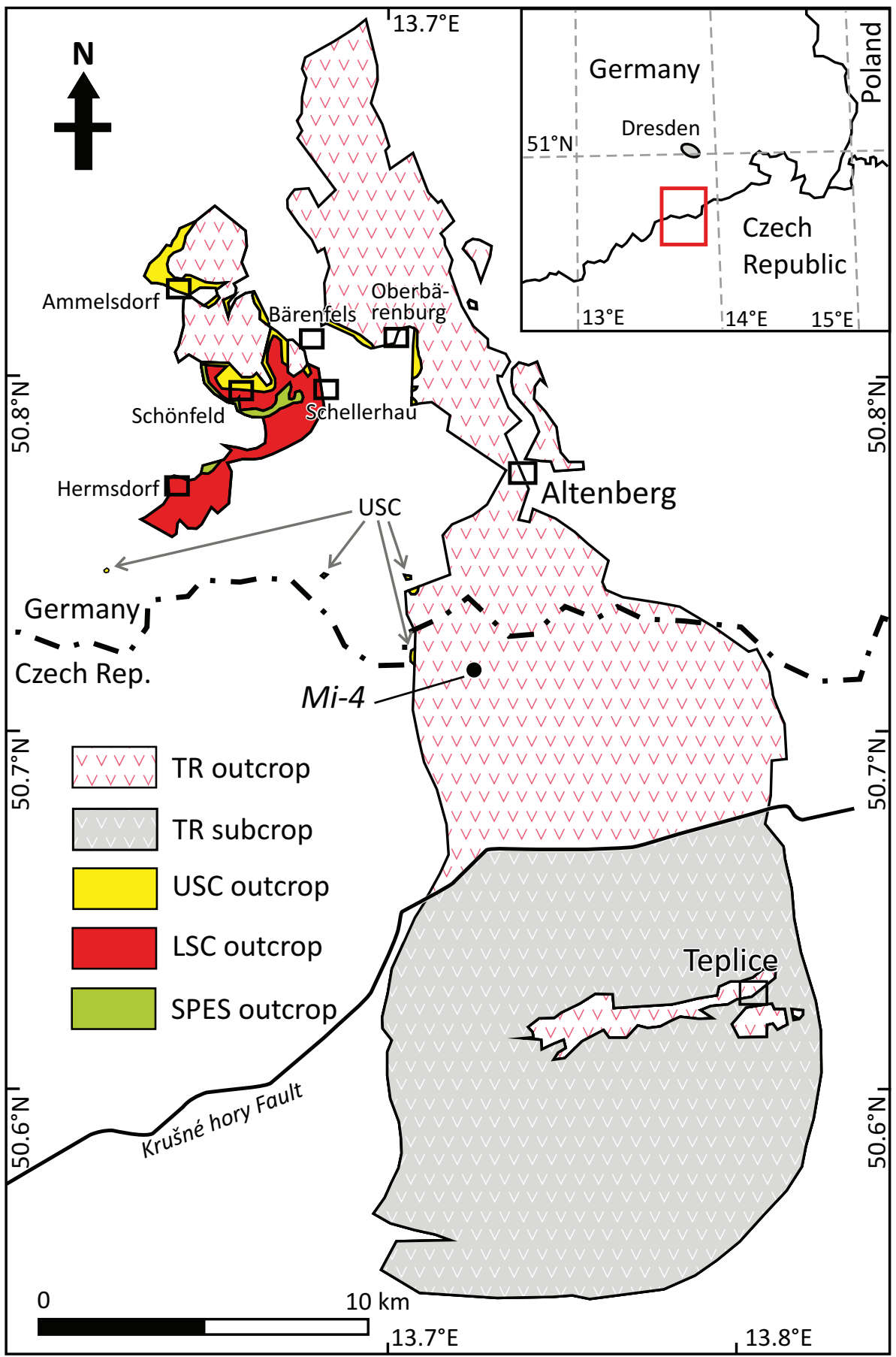

\section{Geological setting and previous studies}

The Schönfeld-Altenberg Depression Complex (SADC) comprises, together with the Teplice Rhyolite (TR), the Altenberg-Teplice Volcanic Complex (ATVC; Moesta 1929). The ATVC is deposited on, and surrounded by, metamorphic rocks of the Saxothuringian nappes (Kroner et al. 2007; Schulmann et al. 2014). Also in the ATVC, metamorphic rocks of the subsided 'Altenberg Block' are exposed. Paragneisses predominate, but remnants of Paleozoic low-grade metamorphic rocks are also preserved (e.g., in the area near Schönfeld, partially underlying the SADC) which mainly consist of phyllites and metabasites (Mlčoch 1989; Hoth et al. 1995).

The undated Fláje biotite granite is considered as pre-TR (Štemprok et al. 2003; Romer et al. 2010) and only future studies may reveal a possible genetic relation to the SADC. The ATVC resembles a large caldera structure with an elliptical shape and

Fig. 1 Geological sketch map of the Altenberg-Teplice Volcanic Complex depicting the out- and subcrop distributions for the Teplice Rhyolite (TR, mainly ignimbrites) and the outcrop area of the Schönfeld-Altenberg Depression Complex; SPES = Schönfeld-Pre-Eruption Sediments, LSC = Lower Schönfeld Complex, USC = Upper Schönfeld Complex (modified after Lobin 1986 and Hoffmann et al. 2013). 


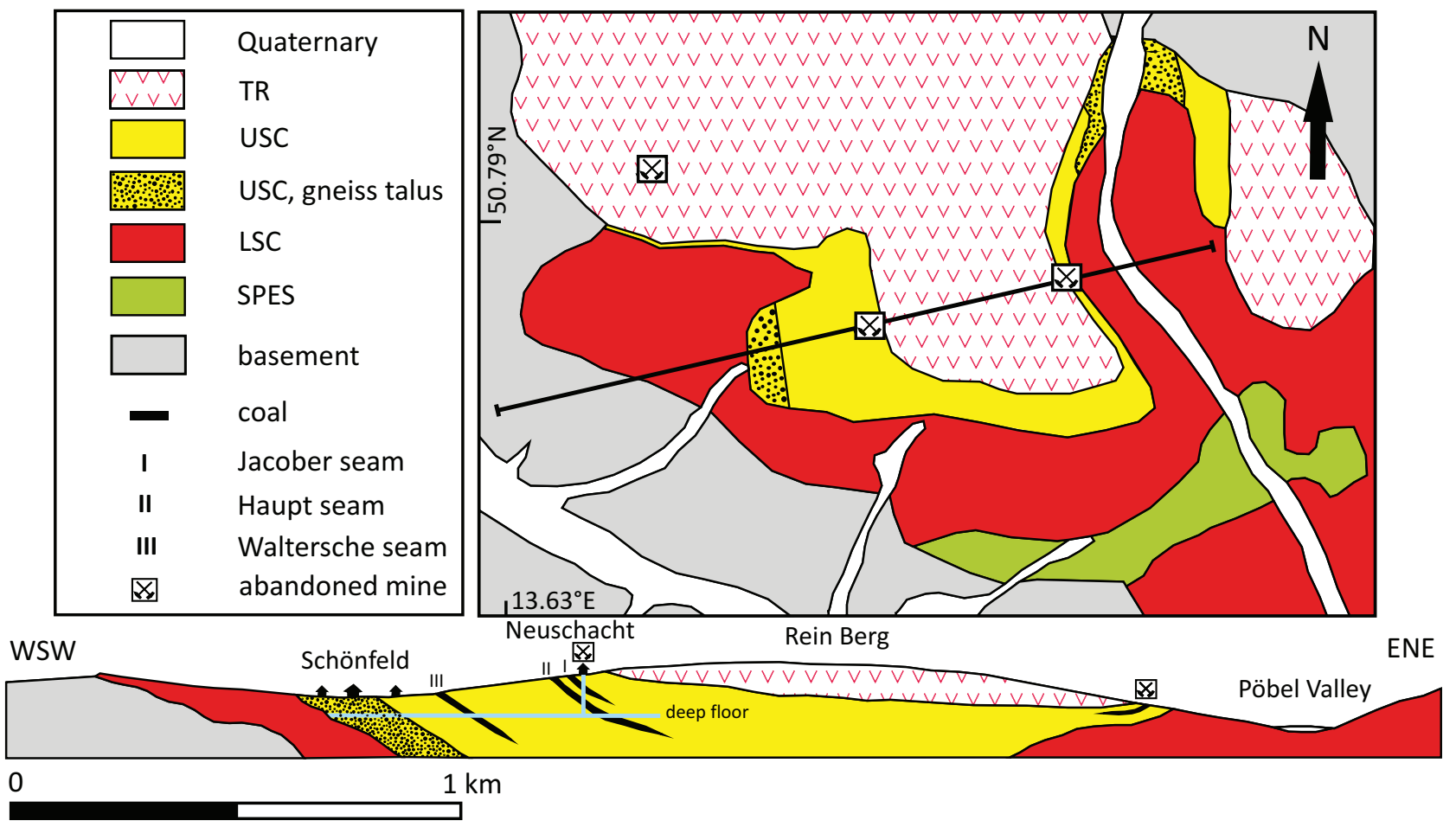

Fig. 2 Geological sketch map of the historic Schönfeld coal mining district (1750-1937) with a profile (Wolf 1960). For explanation of abbreviations, see Fig. 1.

a north-south extent of $c$. 35 km (Fig. 1; Benek 1991; Mlčoch and Skácelová 2010). The TR is a thick rhyolitic caldera-fill succession $(\leq 1000 \mathrm{~m}$, Mlčoch and Skácelová 2010), dominated by crystal-clast- and pumice-rich welded ignimbrites (Lobin 1986). The TR also contains subordinate lava complexes and two intercalations of volcaniclastic sediments, suggesting step-wise caldera evolution. The TR caldera has been characterized as a trap-door type with the strongest subsidence on the eastern side (Benek 1991).

During the late phase of the ATVC evolution, coarsely porphyritic microgranites were emplaced (the AltenbergFrauenstein microgranite; Müller and Seltmann 2002; Müller et al. 2005; Breiter et al. 2012, 2013). These thick porphyry dykes form an almost continuous ring around the ATVC (Müller and Seltmann 2002; Mlčoch and Skácelová 2010). Romer et al. (2010) reported a U-Pb age on zircon of 319.2 \pm 2.4 Ma for a microgranitic dyke crosscutting the Teplice Ignimbrite. Later, monzo- to syenogranites (Schellerhau granite: Pälchen and Ossenkopf 1967) and Sn-Li granites (Altenberg, Cínovec) were also emplaced (Förster et al. 1999; Johan et al. 2012; Štemprok and Blecha 2015; Štemprok 2016). Limicas from the late $\mathrm{Li}$ granites gave $\mathrm{Ar}-\mathrm{Ar}$ ages in the range between $312.6 \pm 2.1$ and $314.9 \pm 2.3$ Ma (Seifert et al. 2011). Molybdenite mineralization in the greisen cupola associated with these late granitic intrusions was dated by Re-Os system (molybdenite) at $323.9 \pm 2.5$ and 317.9 $\pm 2.4 \mathrm{Ma}$ (Romer et al. 2007), as well as at $322.4 \pm 5.5,321.4 \pm 3.8,319.2 \pm 2.0$ and $315.3 \pm 2.0 \mathrm{Ma}$ (Ackerman et al. in print). The existing geochronological data from the post-TR granitic intrusions and related greisens (affecting the pre-existing TR and granite porphyry dykes) indicate that the hiatus between the SADC and the TR, respectively, was significantly shorter than suggested by previous palaeobotanic studies (Lobin 1986).

During the Cenozoic, the northern part of the ATVC was uplifted along the SW-NE-trending Erzgebirge/ Krušné hory Fault, whereas the southern part subsided and is almost completely covered by Mesozoic-Cenozoic sediments (Mlčoch and Skácelová 2010).

Geological interest for the SADC reaches back to the mid- $18^{\text {th }}$ century when extraction of low-volume, highly matured coal seams started in the Schönfeld area (Figs 1-2; Geinitz 1856; Wolf 1960). The SADC has been subdivided (Wolf 1960; Lobin 1986; Schneider et al. 2005; Förster et al. 2008), from base to top, into: the 'Putzmühle Formation' (here named Schönfeld pre-eruption sediments, SPES), the 'Schönfeld Rhyolite' (here Lower Schönfeld Complex, LSC), and the 'Schönfeld Formation' with the overlying 'Mühlwald Formation' (here Upper Schönfeld Complex, USC). Based on our investigation, the old names are not precise enough or misleading; e.g. the "Schönfeld Rhyolite" includes also intermediate volcanic extrusive and intrusive rocks, as well as pyroclastic and sedimentary rocks. For that reason, new 
names have been introduced. Poorly preserved plant remnants collected from the USC have been assigned to the Westphalian B/C (?Lower Moscovian; Geinitz 1856; Gothan 1932; Lobin 1986). Hoffmann et al. (2013) presented a well-constrained $\mathrm{U}-\mathrm{Pb}$ zircon age of $326.8 \pm 4.3$ Ma from the lowermost ignimbrite of the LSC in drillcore Mi-4, suggesting, together with the published radiometric data set displayed above, an assignment of the SADC to the Lower Namurian (Serpukhovian).

Numerous studies (published and unpublished reports, diploma-, bachelor-, master- and PhD studies) have been carried out until the 1980s on the ATVC and underlying metamorphic units. Lobin (1986) compiled a comprehensive review for the German and Jiránek et al. (1987) for the Czech parts.

\section{Methods}

\subsection{Petrography}

Existing outcrops and preserved drill cores from the SADC have been carefully re-evaluated or described and sampled for the first time. More than 500 borehole reports have been examined for the presence of various SADC units and 90 boreholes yielded positive results. Further analytical work focused on drill cores from four selected drills and outcrop samples (Electronic Supplementary Material 1).

Description of volcanic and sedimentary textures includes grain size, content and size of lithics, pumice, phenocrysts and crystal clasts. Modal composition (approx. 1000-1500 points) and maximum particle size (MPS, mean of three largest grains: Tab. 1) have been analysed on rock slabs and in thin sections. Coal-rich layers in the USC of the borehole 2055/85 (Fig. 3) have been sampled for palynological analysis. The attempt was unsuccessful due to a high degree of maturation.

\subsection{Petrophysical properties}

Altogether 78 specimens from drill cores and outcrop samples were measured for petrophysical properties to support the drill-log and geochemical data (Electronic Supplementary Material 2). The bulk-rock magnetic susceptibility was measured by portable kappa-meter KT-6 (SatisGeo, Brno). Samples taken from the drill core were then drilled parallel to the core axes and one or two specimens were obtained $(20 \mathrm{~mm}$ high and $23 \mathrm{~mm}$ in diameter). These specimens were used for complex petromagnetic measurements. The mean magnetic susceptibility $\mathrm{K}_{\text {mean }}$ was measured in the lab of the AGICO, Ltd., Brno, using the Kappabridge KLY2. Laboratory gammaray spectrometry (subcontracted by GeoRadis Brno) was applied on the same samples in order to determine concentrations of elements with naturally radioactive isotopes ( $\mathrm{K}$, Th and $\mathrm{U})$.

\subsection{Bulk-rock geochemistry}

With the aim to classify the LSC and USC volcanic rocks we collected published data, complemented by new geochemical analyses. The published data (major

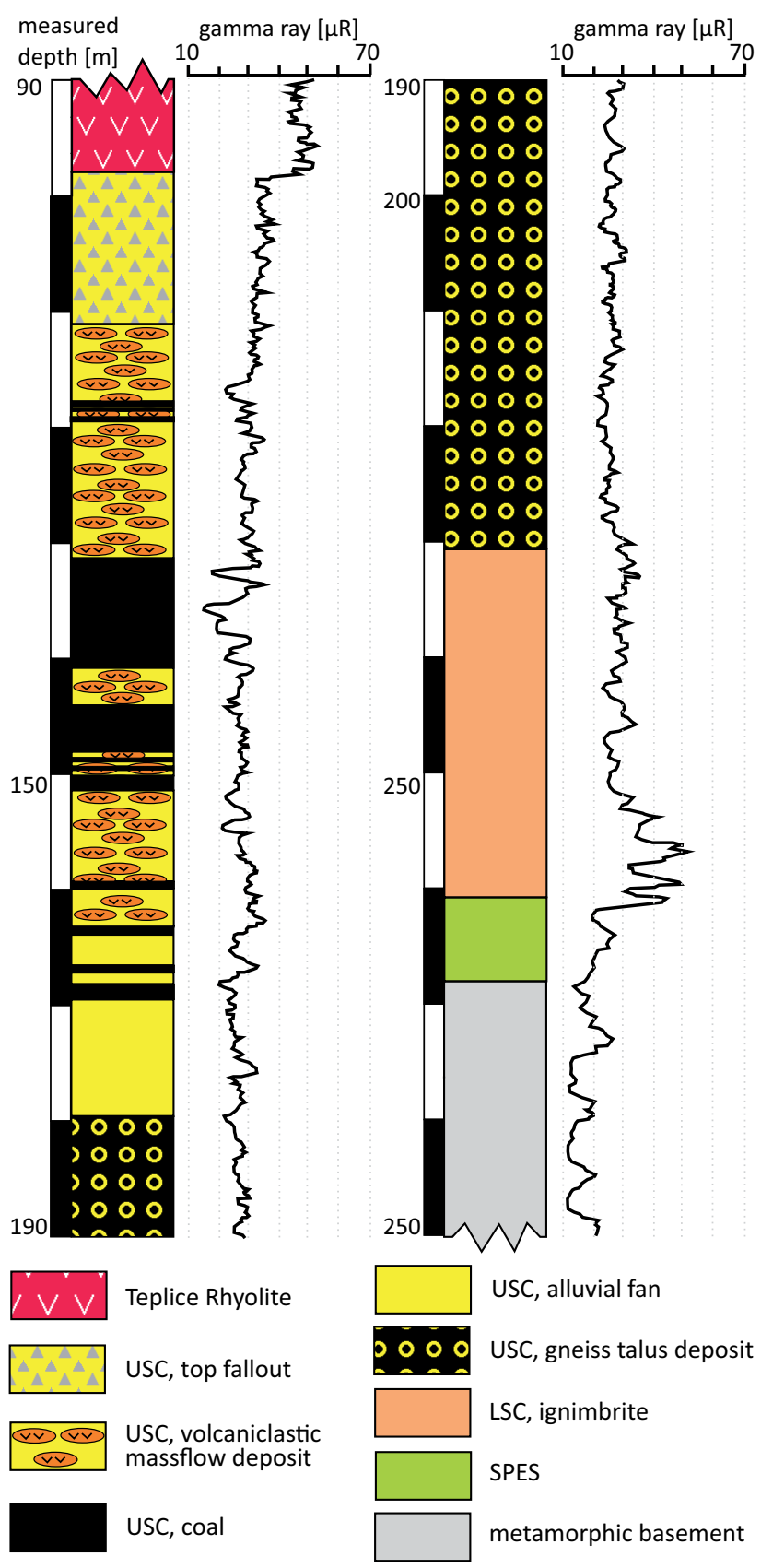

Fig. 3 Section of borehole 2055/85 (for location see Fig. 4a) depicting various Schönfeld-Altenberg Depression Complex units as well as under-/overlying units. 


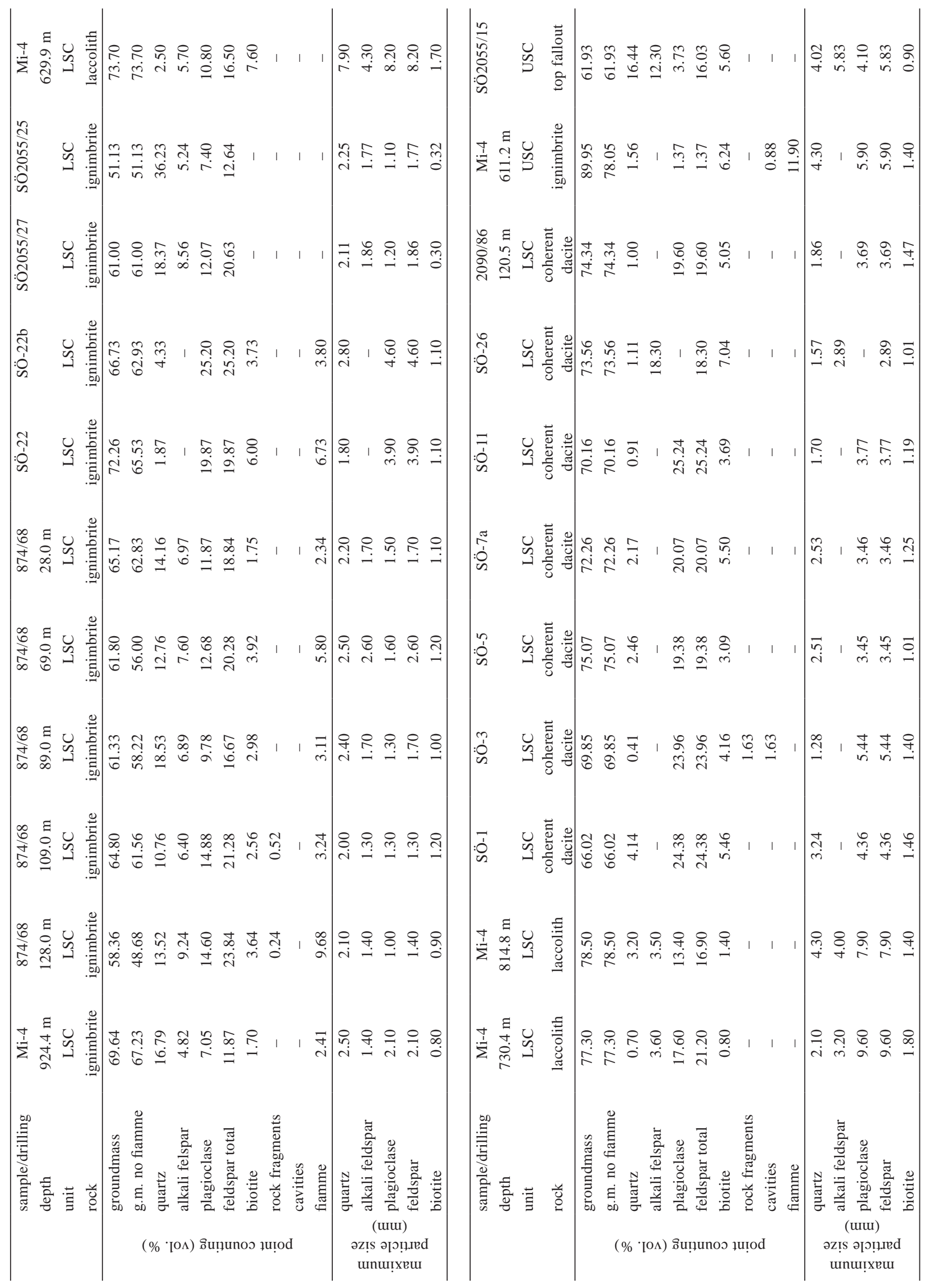




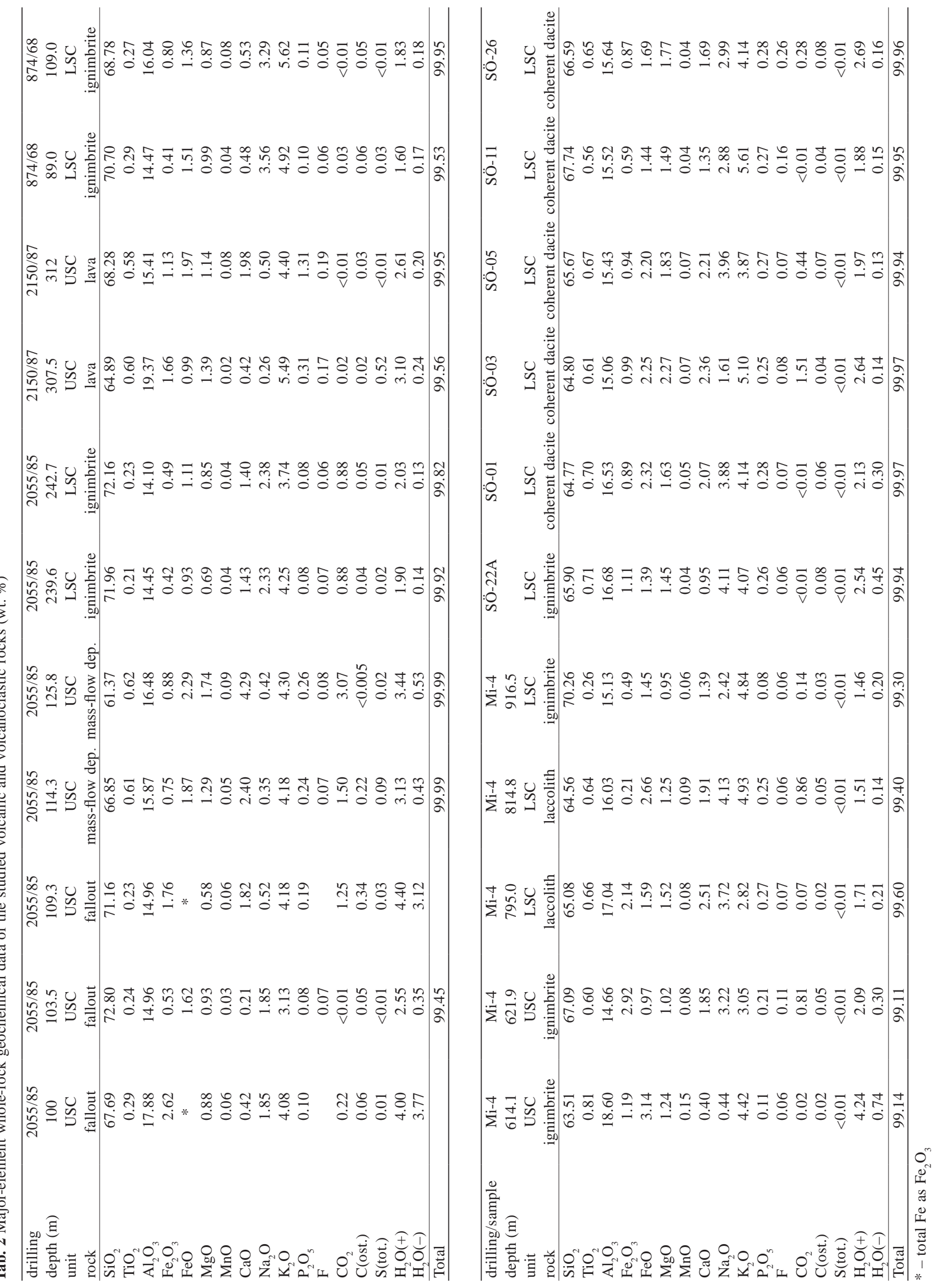


Volcanosedimentary evolution of the Schönfeld-Altenberg Depression

Tab. 3 Trace-element whole-rock geochemical data of the studied volcanic and volcanoclastic rocks (ppm)

\begin{tabular}{|c|c|c|c|c|c|c|c|c|c|c|c|}
\hline drilling & $2055 / 85$ & $2055 / 85$ & $2055 / 85$ & $2055 / 85$ & $2055 / 85$ & $2055 / 85$ & $2055 / 85$ & $2150 / 87$ & $2150 / 87$ & $874 / 68$ & $874 / 68$ \\
\hline depth (m) & 100 & 103.5 & 109.3 & 114.3 & 125.8 & 239.6 & 242.7 & 307.5 & 312 & 89.0 & 109.0 \\
\hline Instrument & ACME & $\mathrm{X}$ Series & ACME & $\mathrm{X}$ Series & $\mathrm{X}$ Series & $\mathrm{X}$ Series & $\mathrm{X}$ Series & $\mathrm{X}$ Series & $\mathrm{X}$ Series & $\mathrm{X}$ Series & $X$ Series \\
\hline $\mathrm{Ba}$ & 354 & 254 & 400 & 500 & 725 & 597 & 487 & 623 & 1077 & 660 & 529 \\
\hline Co & 2.4 & & 2.5 & & & & & & & & \\
\hline $\mathrm{Cr}$ & 20 & 5 & 13 & 34 & 22 & 16 & 15 & 40 & 34 & 20 & 15 \\
\hline Cs & 63.8 & & & & & & & & & & \\
\hline $\mathrm{Cu}$ & $<1$ & & 2 & & & & & & & & \\
\hline Ga & 26 & 23 & 24 & 23 & 24 & 21 & 20 & 28 & 22 & 23 & 25 \\
\hline Hf & 3.7 & 1.2 & 3.3 & 2.3 & 2.7 & 3.4 & 3.0 & 3.7 & 3.4 & 3.4 & 2.8 \\
\hline $\mathrm{Nb}$ & 14 & 10 & 12 & 11 & 11 & 5.0 & 8.0 & 14 & 10 & 10 & 8 \\
\hline $\mathrm{Ni}$ & 2 & 16 & 2 & 20 & 19 & 19 & 16 & 26 & 24 & 14 & 18 \\
\hline $\mathrm{Pb}$ & 38 & 43 & 33 & 21 & 25 & 40 & 29 & 24 & 21 & 52 & 38 \\
\hline $\mathrm{Rb}$ & 358 & 281 & 325 & 256 & 286 & 324 & 244 & 418 & 320 & 230 & 260 \\
\hline Sr & 15 & 43 & 12 & 66 & 96 & 192 & 161 & 43 & 44 & 187 & 169 \\
\hline Th & 14 & 4.1 & 11 & 6.7 & 13 & 9.0 & 8.0 & 24 & 28 & 10 & 8.4 \\
\hline $\mathrm{U}$ & 19 & 10 & 16 & 6.5 & 7.2 & 11 & 10 & 9 & 12 & 23 & 13 \\
\hline V & 17 & 14 & 22 & 63 & 46 & 13 & 21 & 70 & 57 & 21 & 21 \\
\hline $\mathrm{Zr}$ & 108 & 93 & 100 & 181 & 185 & 100 & 94 & 240 & 196 & 123 & 113 \\
\hline Zn & 73 & & 65 & & & & & & & & \\
\hline $\mathrm{Y}$ & 13 & 10 & 15 & 17 & 18 & 15 & 14 & 24 & 35 & 20 & 18 \\
\hline $\mathrm{La}$ & 26 & 23 & 22 & 38 & 41 & 22 & 18 & 58 & 57 & 20 & 19 \\
\hline $\mathrm{Ce}$ & 51 & 51 & 43 & 81 & 88 & 44 & 38 & 128 & 115 & 41 & 40 \\
\hline $\operatorname{Pr}$ & 6 & 6 & 5 & 9 & 9 & 5 & 4 & 14 & 12 & 5 & 5 \\
\hline $\mathrm{Nd}$ & 20 & 19 & 18 & 29 & 31 & 18 & 15 & 45 & 40 & 17 & 17 \\
\hline Sm & 4.8 & 4.2 & 4.6 & 5.0 & 5.4 & 3.5 & 2.9 & 8.1 & 7.4 & 3.6 & 3.4 \\
\hline $\mathrm{Eu}$ & 0.55 & 0.70 & 0.46 & 1.57 & 1.64 & 0.73 & 0.59 & 2.20 & 2.41 & 0.72 & 0.64 \\
\hline Gd & 4.0 & 2.8 & 4.1 & 3.6 & 3.8 & 2.8 & 2.4 & 5.7 & 5.5 & 3.1 & 2.9 \\
\hline $\mathrm{Tb}$ & 0.5 & 0.5 & 0.5 & 0.6 & 0.7 & 0.5 & 0.5 & 1.1 & 1.0 & 0.6 & 0.6 \\
\hline Dy & 2.5 & 2.5 & 2.7 & 3.2 & 3.4 & 2.8 & 2.4 & 4.9 & 5.6 & 3.5 & 3.2 \\
\hline Ho & 0.38 & 0.42 & 0.42 & 0.64 & 0.69 & 0.52 & 0.49 & 0.97 & 1.05 & 0.70 & 0.65 \\
\hline Er & 1.05 & 1.04 & 1.18 & 1.84 & 1.79 & 1.38 & 1.27 & 2.53 & 2.89 & 1.83 & 1.67 \\
\hline $\mathrm{Tm}$ & 0.17 & 0.15 & 0.16 & 0.24 & 0.22 & 0.22 & 0.22 & 0.32 & 0.40 & 0.28 & 0.28 \\
\hline $\mathrm{Yb}$ & 0.93 & 0.97 & 0.95 & 1.60 & 1.56 & 1.34 & 1.28 & 2.24 & 2.42 & 1.76 & 1.66 \\
\hline $\mathrm{Lu}$ & 0.15 & 0.13 & 0.16 & 0.25 & 0.23 & 0.21 & 0.19 & 0.31 & 0.38 & 0.25 & 0.26 \\
\hline
\end{tabular}

oxides) originate from outcrop samples (Wetzel 1984; see Electronic Supplementary Material 3).

Twenty-two representative samples collected from drill cores (Mi-4, 2055/85, 2150/87 and 874/68) and natural outcrops were analysed for the present study (Tabs 2 and 3).

Major-element analyses were carried out in the laboratories of the Czech Geological Survey, Prague. The analytical methods included atomic absorption spectrometry, photometry and titration with complexon III, following methods described by Dempírová et al. (2010).

The trace-element concentrations in the samples from outcrops and drill cores 2055/85, 2150/87 and 874/68 have been measured using a ARL9400 XRF analyzer $(\mathrm{Cr}, \mathrm{Nb}, \mathrm{Ni}, \mathrm{V})$ or a ThermoFisher Scientific $X$ Series II ICP-MS (Ba, Ga, Hf, Pb, Rb, Sr, Th, U, Zr, Y, REE), both housed at the Czech Geological Survey in Prague (CGS). For the ICP-MS determinations, the sample decomposition involved fusion in a Pt-beaker with $\mathrm{LiBO}_{2}-\mathrm{Na}_{2} \mathrm{CO}_{3}$ mixture. The trace-element concentrations in the Mi-4 drill core samples were measured using an Agilent 7900x ICP-MS (Ba, Co, Cr, Cs, Cu, Ga, Hf, Li, Nb, Ni, Pb, Rb, Sc, Sr, Ta, Th, Tl, U, V, W, Zn, Zr, Y, REE), housed at the CGS, following dissolution in a mixture of concentrated $\mathrm{HNO}_{3}-\mathrm{HF}$ and equilibration with $\mathrm{HCl}$. Basalt BHVO-2 (USGS) and rhyolite JR-2 (GSJ) were run together with unknown samples for quality control (Electronic Supplementary Material 4). Their concentrations are in agreement with published values (Jochum et al. 2005).

The dataset was supplemented by two samples (2055_100 and 2055_109; Tabs 2 and 3) of the USC top fallout analysed for major- and trace-elements in the ACME laboratories, Vancouver, Canada using the LF202 method package. Major-element concentrations were obtained by Inductively-Coupled Plasma Emission Spectrometry (ICP-ES), trace-element concentrations by Inductively-Coupled Plasma Mass Spectrometry (ICP-MS). The sample was leached in hot aqua regia for determination of $\mathrm{Cu}, \mathrm{Ni}, \mathrm{Pb}$ and $\mathrm{Zn}$, whereas for 
Tab. 3 Continued

\begin{tabular}{|c|c|c|c|c|c|c|c|c|c|c|c|}
\hline drill./sample & $\mathrm{Mi}-4$ & $\mathrm{Mi}-4$ & $\mathrm{Mi}-4$ & $\mathrm{Mi}-4$ & $\mathrm{Mi}-4$ & SÖ-22A & SÖ-01 & SÖ-03 & SÖ-05 & SÖ-11 & SÖ-26 \\
\hline depth (m) & 614.1 & 621.9 & 795.0 & 814.8 & 916.5 & & & & & & \\
\hline Instrument & Agilent & Agilent & Agilent & Agilent & Agilent & $\mathrm{X}$ Series & $\mathrm{X}$ Series & $\mathrm{X}$ Series & X Series & X Series & $\mathrm{X}$ Series \\
\hline $\mathrm{Ba}$ & 657 & 534 & 601 & 904 & 551 & 850 & 824 & 1125 & 815 & 1393 & 755 \\
\hline Co & 10 & 6.2 & 7.1 & 7.7 & 2.6 & & & & & & \\
\hline $\mathrm{Cr}$ & 42 & 33 & 39 & 34 & 16 & 32 & 29 & 29 & 33 & 36 & 30 \\
\hline Cs & 26 & 24 & 15 & 5 & 14 & & & & & & \\
\hline $\mathrm{Cu}$ & 2.4 & 13 & 5.6 & 2.7 & 2.1 & & & & & & \\
\hline $\mathrm{Ga}$ & 24 & 19 & 19 & 16 & 18 & 24 & 27 & 23 & 23 & 26 & 23 \\
\hline Hf & 5.2 & 4.7 & 4.3 & 4.2 & 3.3 & 4.1 & 4.1 & 3.7 & 2.9 & 3.1 & 3.3 \\
\hline $\mathrm{Li}$ & 39 & 44 & 38 & 54 & 39 & & & & & & \\
\hline $\mathrm{Nb}$ & 19 & 15 & 18 & 16 & 14 & 11 & 10 & 10 & 10 & 10 & 11 \\
\hline $\mathrm{Ni}$ & 22 & 16 & 19 & 16 & 7.2 & 13 & 19 & 21 & 15 & 22 & 19 \\
\hline $\mathrm{Pb}$ & 20 & 17 & 24 & 68 & 39 & 21 & 40 & 27 & 33 & 24 & 12 \\
\hline $\mathrm{Rb}$ & 229 & 168 & 134 & 206 & 219 & 170 & 183 & 299 & 143 & 371 & 278 \\
\hline Sc & 9.8 & 7.4 & 8.1 & 7.8 & 4.9 & & & & & & \\
\hline $\mathrm{Sr}$ & 70 & 182 & 433 & 308 & 190 & 334 & 443 & 390 & 415 & 404 & 327 \\
\hline $\mathrm{Ta}$ & 1.6 & 1.3 & 1.5 & 1.5 & 1.2 & & & & & & \\
\hline Th & 27 & 19 & 20 & 19 & 15 & 11 & 11 & 9.1 & 7.7 & 7.8 & 7.9 \\
\hline $\mathrm{Tl}$ & 1.2 & 1.0 & 0.6 & 1.2 & 1.1 & & & & & & \\
\hline $\mathrm{U}$ & 10.3 & 8.3 & 8.9 & 6.6 & 7.2 & 10 & 11 & 7.8 & 8.8 & 10 & 9.4 \\
\hline $\mathrm{V}$ & 96 & 88 & 99 & 94 & 65 & 67 & 56 & 56 & 48 & 61 & 62 \\
\hline W & 3.6 & 2.6 & 2.6 & 2.0 & 3.1 & & & & & & \\
\hline $\mathrm{Zr}$ & 211 & 185 & 165 & 162 & 93 & 222 & 226 & 213 & 187 & 202 & 205 \\
\hline $\mathrm{Zn}$ & 84 & 65 & 55 & 61 & 50 & & & & & & \\
\hline $\mathrm{Y}$ & 24 & 20 & 18 & 15 & 17 & 15 & 18 & 20 & 15 & 16 & 17 \\
\hline $\mathrm{La}$ & 67 & 44 & 47 & 42 & 27 & 17 & 41 & 41 & 38 & 39 & 36 \\
\hline $\mathrm{Ce}$ & 137 & 89 & 96 & 88 & 58 & 41 & 80 & 65 & 73 & 75 & 84 \\
\hline $\operatorname{Pr}$ & 14 & 10 & 10 & 9 & 6 & 4 & 9 & 8 & 8 & 8 & 8 \\
\hline $\mathrm{Nd}$ & 53 & 36 & 36 & 34 & 21 & 18 & 32 & 32 & 29 & 30 & 29 \\
\hline $\mathrm{Sm}$ & 9.6 & 6.5 & 6.2 & 6.0 & 4.2 & 4.1 & 5.7 & 5.4 & 5.0 & 5.2 & 5.3 \\
\hline $\mathrm{Eu}$ & 2.08 & 1.39 & 1.41 & 1.44 & 0.76 & 0.98 & 1.37 & 1.42 & 1.20 & 1.42 & 1.34 \\
\hline Gd & 8.4 & 5.8 & 5.4 & 5.0 & 3.8 & 3.2 & 4.7 & 4.4 & 4.2 & 4.4 & 4.5 \\
\hline $\mathrm{Tb}$ & 1.1 & 0.8 & 0.7 & 0.7 & 0.6 & 0.6 & 0.7 & 0.7 & 0.6 & 0.7 & 0.7 \\
\hline Dy & 5.1 & 3.7 & 3.2 & 3.0 & 3.0 & 2.9 & 3.5 & 3.3 & 2.9 & 3.1 & 3.1 \\
\hline Ho & 1.04 & 0.80 & 0.70 & 0.63 & 0.68 & 0.52 & 0.63 & 0.61 & 0.52 & 0.57 & 0.58 \\
\hline $\mathrm{Er}$ & 2.75 & 2.13 & 1.91 & 1.66 & 1.92 & 1.37 & 1.69 & 1.50 & 1.36 & 1.43 & 1.55 \\
\hline $\mathrm{Tm}$ & 0.36 & 0.29 & 0.26 & 0.22 & 0.26 & 0.22 & 0.25 & 0.22 & 0.20 & 0.22 & 0.23 \\
\hline $\mathrm{Yb}$ & 2.29 & 1.80 & 1.63 & 1.38 & 1.71 & 1.33 & 1.52 & 1.40 & 1.24 & 1.38 & 1.41 \\
\hline $\mathrm{Lu}$ & 0.32 & 0.23 & 0.21 & 0.16 & 0.21 & 0.22 & 0.24 & 0.22 & 0.19 & 0.22 & 0.21 \\
\hline
\end{tabular}

determinations of major-elements and remaining traceelements the sample was fused with Li-tetraborate prior to leaching in acids (see http://acmelab.com for further analytical details).

\section{4. $\mathrm{Sr}-\mathrm{Nd}$ isotopes}

Four representative samples corresponding to the main units were selected for the $\mathrm{Sr}-\mathrm{Nd}$ isotope analysis (Tab. 4). Approximately $100 \mathrm{mg}$ of a powdered sample was digested in $\sim 2: 1 \mathrm{HF}-\mathrm{HNO}_{3}$ mixture at $140^{\circ} \mathrm{C}$. After evaporation, the samples were dried down repeatedly with $2 \mathrm{ml}$ of concentrated $\mathrm{HNO}_{3}$, and once with $500 \mu \mathrm{l}$ of $1 \mathrm{M} \mathrm{HNO}_{3}-0.1 \mathrm{M}$ ascorbic acid to reduce the amount of
$\mathrm{Fe}^{\mathrm{III}}$. Strontium and REE fractions were isolated from the bulk matrix by the column chromatography techniques using a $4 \mathrm{ml}$ column packed with Bio Rad AG50W-X8 resin (200-400 mesh). The Sr-spec resin (Triskem Int.) was used for isolation of Sr (Pin et al. 2014). The Nd was separated using the Ln resin (Pin and Zalduegui 1997). Strontium and neodymium isotopic analyses were performed on a Finnigan MAT 262 thermal ionization mass spectrometer housed at CGS, in dynamic mode using a single Ta filament for $\mathrm{Sr}$ and double Re filament assembly for $\mathrm{Nd}$. The ${ }^{143} \mathrm{Nd} /{ }^{144} \mathrm{Nd}$ and ${ }^{87} \mathrm{Sr} /{ }^{86} \mathrm{Sr}$ ratios were corrected for mass fractionation assuming ${ }^{146} \mathrm{Nd} /{ }^{144} \mathrm{Nd}=0.7219$ and ${ }^{86} \mathrm{Sr} /{ }^{88} \mathrm{Sr}=0.1194$, respectively. External reproducibility was estimated from replicate analyses of the JNdi-1 
Tab. 4 Sr-Nd isotope data of the studied volcanic and volcaniclastic rocks

\begin{tabular}{|c|c|c|c|c|c|c|c|c|c|c|c|}
\hline Sample & Age (Ma) & Sr (ppm) & $\mathrm{Rb}(\mathrm{ppm})$ & Nd (ppm) & Sm (ppm) & ${ }^{87} \mathrm{Sr} /{ }^{86} \mathrm{Sr}_{\mathrm{i}}$ & ${ }^{87} \mathrm{Rb} /{ }^{86} \mathrm{Sr}$ & ${ }^{143} \mathrm{Nd} /{ }^{144} \mathrm{Nd} \mathrm{i}_{\mathrm{i}}$ & ${ }^{147} \mathrm{Sm} /{ }^{144} \mathrm{Nd}$ & $\varepsilon \mathrm{Nd}_{\mathrm{i}}$ & $\mathrm{T}_{\text {DMII }}^{\mathrm{Nd}}$ \\
\hline Mi-4/614 & 325 & 70 & 229 & 53.4 & 9.62 & 0.70626 & 9.5629 & 0.51210 & 0.1089 & -2.4 & 1.2 \\
\hline Mi-4/814 & 325 & 308 & 206 & 33.6 & 5.98 & 0.70614 & 1.9372 & 0.51208 & 0.1076 & -2.7 & 1.3 \\
\hline Mi-4/916 & 325 & 190 & 219 & 21.2 & 4.20 & 0.70556 & 3.3404 & 0.51208 & 0.1198 & -2.7 & 1.3 \\
\hline SÖ-01 & 325 & 443 & 183 & 32.3 & 5.66 & 0.70598 & 1.1974 & 0.51205 & 0.1059 & -3.3 & 1.3 \\
\hline
\end{tabular}

$\mathrm{Sr}, \mathrm{Rb}, \mathrm{Nd}, \mathrm{Sm}$ concentrations were measured by ICP MS

$\left({ }^{143} \mathrm{Nd} /{ }^{144} \mathrm{Nd}=0.512109 \pm 23,2 \sigma ; \mathrm{n}=9\right)$ and NBS 987 $\left({ }^{87} \mathrm{Sr} /{ }^{86} \mathrm{Sr}=0.710240 \pm 19,2 \sigma ; \mathrm{n}=13\right)$ isotopic standards. The initial isotopic ratios (325 Ma) were calculated using decay constants given by Steiger and Jäger (1977; Sr) and Lugmair and Marti (1978; Nd). The $\varepsilon_{\mathrm{Nd}}$ values were obtained using Bulk Earth parameters of Jacobsen and Wasserburg (1980), the single- and two-stage depleted mantle Nd model ages ( $\mathrm{T}_{\text {DM }}^{\mathrm{Nd}}$ and $\mathrm{T}_{\text {DMII }}^{\mathrm{Nd}}$ ) were calculated after Liew and Hofmann (1988).

\section{Results}

\subsection{Distribution, lithostratigraphy, petrography and petrophysical characteristics of the SADC}

Main outcrops of SADC rocks are present near the villages of Ammelsdorf, Bärenfels, Hermsdorf and Schönfeld (Fig. 1). Small isolated outcrops have been reported by Lobin (1986) from the area west of Altenberg. In the German part of ATVC numerous exploration boreholes detected SADC rocks, covered in places by TR volcanics (Fig. 4). In the Czech Republic, only the borehole Mi-4 penetrated a thick SADC succession (Figs 1, 5). Field relations (Beck 1887) reveal three types of contact with the metamorphic basement: (i) depositional (e.g., near Schönfeld), (ii) faulted (e.g., southeast of Hermsdorf), and (iii) intrusive (northeast of Hermsdorf).

Schönfeld pre-eruptive sediments (SPES), mapped in the area between Ammelsdorf and Hermsdorf, comprise up to $60 \mathrm{~m}$ of non-volcanogenic, sandy conglomerates to conglomerates (Fig. 4a). They formed in alluvial fan and fluvial environments, accumulating gneiss debris and thin, highly mature, vitrain coal horizons (Lobin 1986, and references therein). Fine- to medium-grained sandstones and carbonaceous claystones dominate the region near Hermsdorf. East of Schönfeld, rounded cobbles up to $50 \mathrm{~cm}$ in size occur representing various types of gneiss, vein quartz and quartzite. Notably, granitoid clasts are absent.

For the region north of Ammelsdorf, Lobin (1986) depicted out- and subcrops of clastic deposits assigned to the SPES. During revisiting the outcrops and re-evaluation of borehole records (in particular drilling 2067/85; Fig. 4b), we detected volcanic clasts making an association with
USC (Upper Schönfeld Complex) more likely (Fig. 4c). Also the thickness of up to $110 \mathrm{~m}$ (Lobin 1986) renders attribution to the USC more probable. Also in borehole 2142/87, located about $5 \mathrm{~km}$ north of Oberbärenburg, a conglomerate of $5.5 \mathrm{~m}$ thickness comprising gneiss clasts has been detected and attributed to the SPES (Fig. 4a).

Near Hermsdorf a coal exploration tunnel was excavated; Geinitz (1856) collected poor plant remains (Lycopodiaceae) from the heaps. In drillcore 2055/85 sediments with a coaly-silty matrix and medium sand- to granule-sized components were identified (bed thickness $\leq 1 \mathrm{~m}$ ); two intercalations (20 and $40 \mathrm{~cm}$ ) of anthracite coal beds have been observed (Fig. 3). Finally, Dalmer (1890) reported a succession (a few metres thick) of gneiss conglomerates, sandstones and anthracite layers detected in a tin mine east of Altenberg (Zwitterstock, “Z” in Fig. 4a; see also Lobin 1986).

In all analysed boreholes, the SPES and the underlying metamorphic basement have lower total gamma radiation values compared to the LSC volcanics (e.g. Figs 3, 5). Magnetic susceptibility of USC rocks in drillcores 2055/85, 2150/87 and Mi-4 match, ranging between $70 \times 10^{-6}$ and $200 \times 10^{-6}$ SI (Fig. 5, Electronic Supplementary Material 2).

Lower Schönfeld Complex (LSC) occurs in a continuous strip of outcrops between Hermsdorf and Bärenfels (Figs 1, 4b). Furthermore, the LSC has been identified in boreholes below the TR in the area between Schönfeld and Ammelsdorf, north and south of Altenberg (Fig. 4b), and in Mi-4 (Fig. 5). Finally, in the northern ATVC, LSC rocks have been observed in boreholes 2142/87 and 2067/85, covered by the TR (Fig. 4b). Lobin (1986) reported a thickness of up to $160 \mathrm{~m}$ for the LSC. However, in Mi-4 (Fig. 5) we assign $304 \mathrm{~m}$ of volcanic and subvolcanic rocks to the LSC, based on whole-rock geochemistry.

Our observations reveal that the LSC comprises two volcanic facies: (i) fine- to coarse-grained ignimbrites and fallout tuffs, and (ii) a complex of lava and subvolcanic bodies including weakly porphyritic rocks of dacite and trachydacite to rhyolite composition.

In the Hermsdorf area numerous boreholes and outcrops document a fine-grained, crystal-rich ignimbrite (drilling 874/68: $153 \mathrm{~m}$ thickness). The lower part of the ignimbrite is formed by a tuff, with intercalations of anthracite $(\leq 1 \mathrm{~m})$ and carbonaceous claystone $(\leq 2$ 

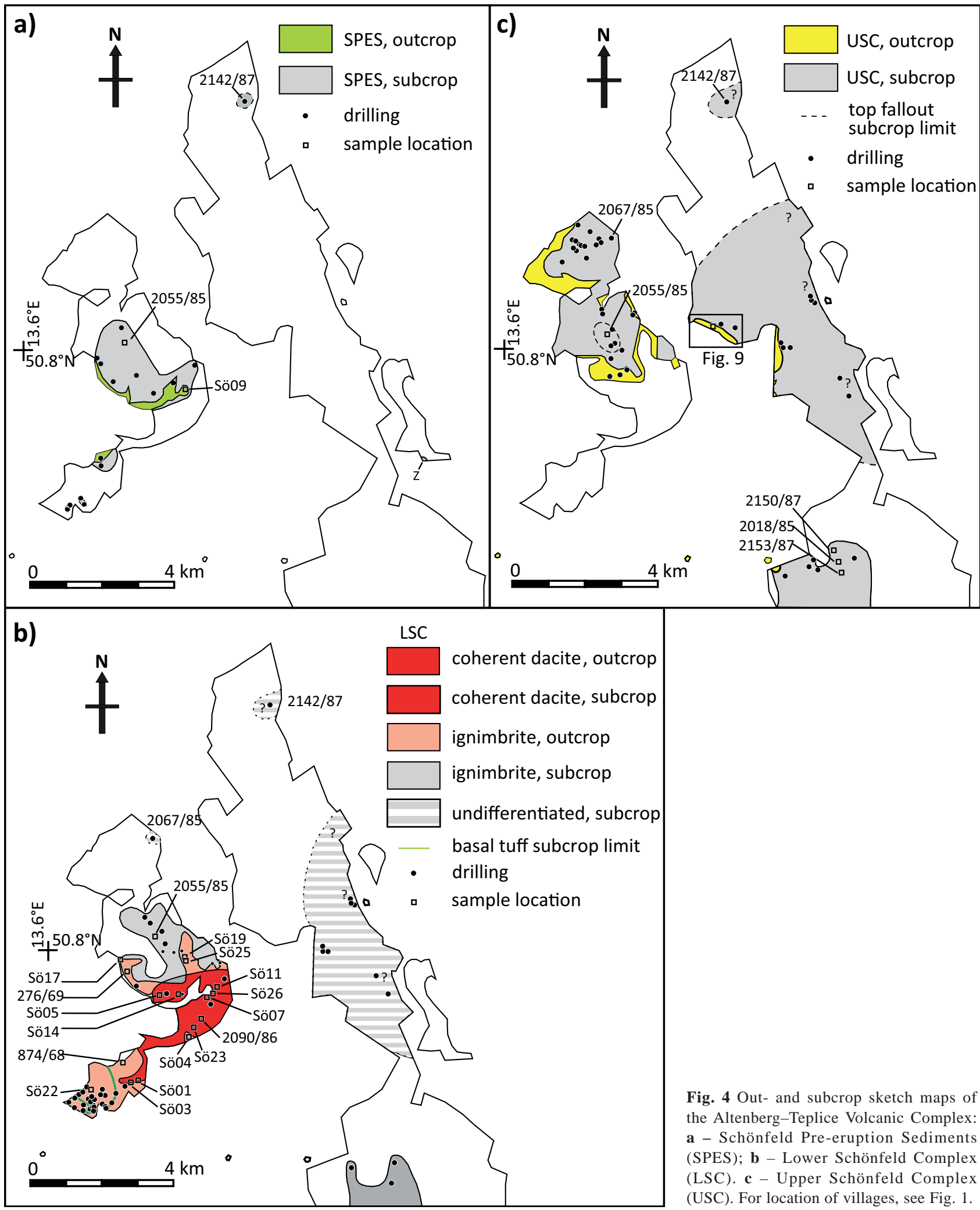

Fig. 4 Out- and subcrop sketch maps of the Altenberg-Teplice Volcanic Complex: a - Schönfeld Pre-eruption Sediments (SPES); b - Lower Schönfeld Complex (LSC). c - Upper Schönfeld Complex (USC). For location of villages, see Fig. 1.

$\mathrm{m})$, indicating an episodic explosive activity at the early stage of the LSC deposition (Fig. 4b; Lobin 1986). Further occurrences of fine-grained, crystal-rich ignimbrites have been documented in boreholes 2055/85 (30 m) and
Mi-4 (54 m; Figs 3, 5) resting on SPES or directly on metamorphic basement, respectively. The weakly welded ignimbrites reveal crystal clast content ranging from 30 to 50 vol. \% (Figs 6e-f, 7e-f, 8a; Tab. 1) with maximum 
particle size (MPS) between 1 and 3 mm (Fig. 8b).

Further occurrences of LSC ignimbrites with plagioclase clasts up to $5.4 \mathrm{~mm}$ (Fig. 8b) have been detected in the Hermsdorf quarry, at outcrops $2 \mathrm{~km}$ NE of Hermsdorf, in borehole 276/69 in Schönfeld, and at outcrops in the Pöbelbach Valley northeast of Schönfeld (Fig. 4b). Field relations in the Hermsdorf area suggest that the coarse-grained ignimbrites are younger than the thick fine-grained unit described above. However, stratigraphic position of the isolated outcrops within the LSC remains unclear.

Lobin (1986) documented a number of boreholes drilled in the Hermsdorf area, where the LSC ignimbrites are clearly overlain by LSC lava. In a continuous strip of outcrops from Hermsdorf to Schellerhau, flowbanded, in places lithophysae-bearing porphyritic lava and subvolcanic bodies occur. The partly subvolcanic character is suggested on the basis of intrusive field relations with the metamorphic basement and with the SPES, and due to the absence of textures typical of lava carapace as described on drill cores of lava complexes in the US by Manley and Fink (1987). The altered coherent rocks contain 20 to 35 vol. \% of phenocrysts (plagioclase and biotite - Figs 6d, 7d, 8a) and varying amounts of quartz xenocrysts, more frequent in isolated lenses in the coherent dacite.

In Mi-4, a c. 250 m thick homogeneous body of porphyritic volcanic rock was discovered overlying fine-grained LSC ignimbrites (Figs $5,6 c, 7 c)$. It is covered, with a sharp contact, by USC ignimbrite. A lack of a top breccia and of other typical carapace textures in the upper part of this body justifies the interpretation of this unit as a laccolith. The higher

Fig. 5 Section of borehole Mikulov Mi-4 depicting the distribution of the SADC rocks and the under-/overlying units. For location, see Fig. 1. Geophysical drill-logs adapted from Eisenreich (1985).

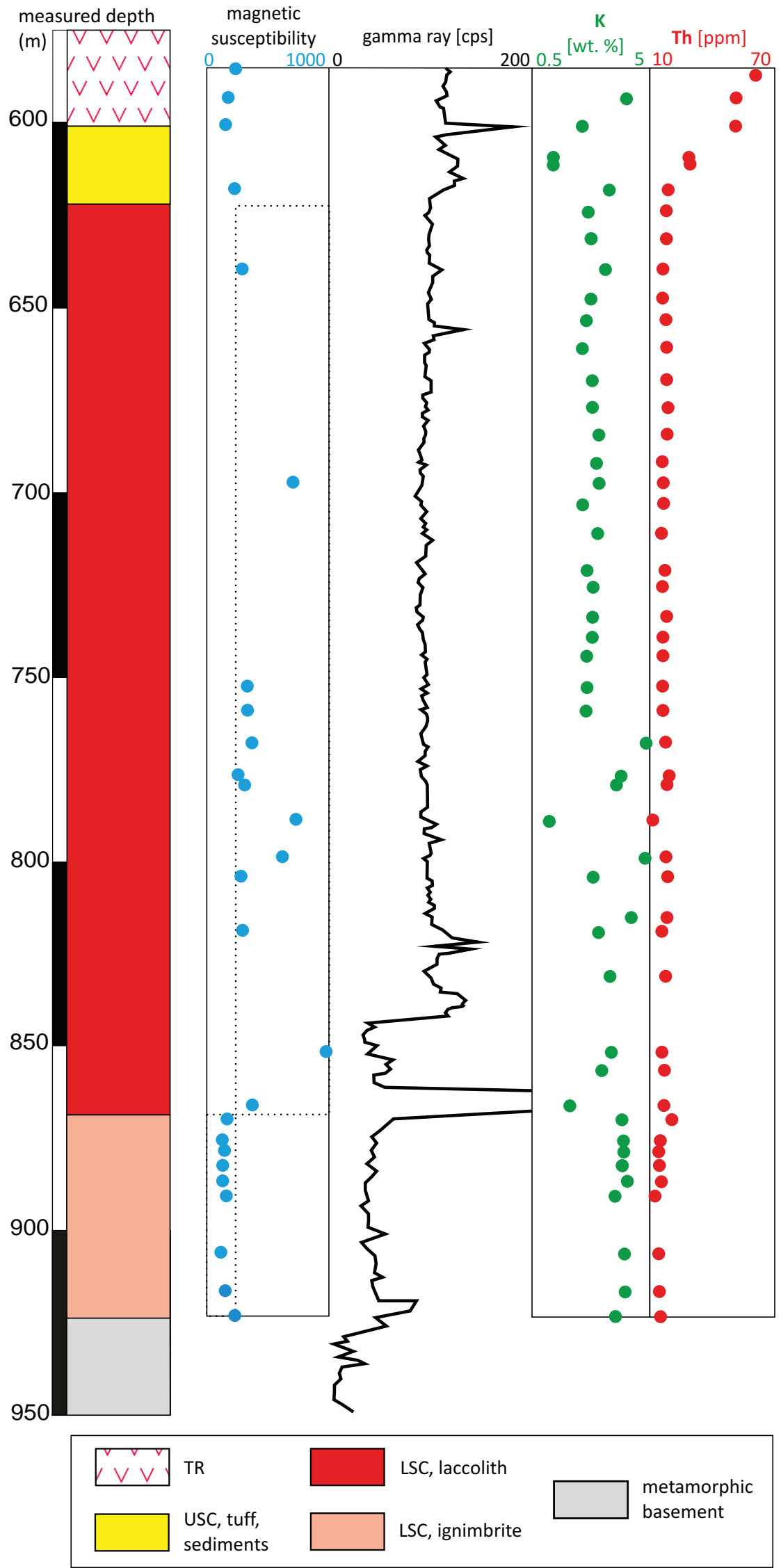



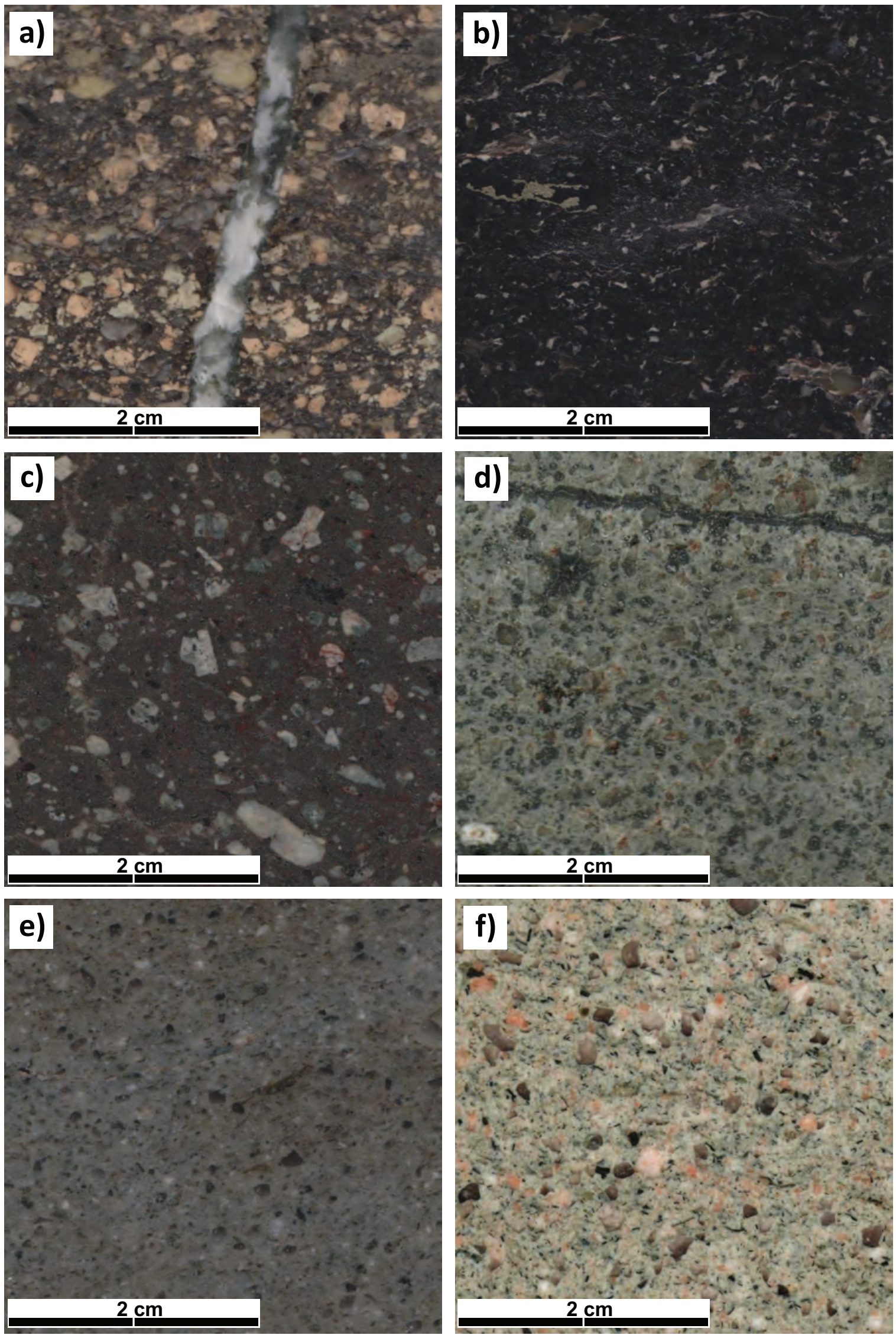
alkalis content (above 6.5 wt. \%) suggests a likely geochemical affinity to the LSC association.

The LSC ignimbrite in Mi-4 displays lower susceptibility values $\left(<200 \times 10^{-6} \mathrm{SI}\right)$ than the overlying laccolith unit (200-870 $\times 10^{-6}$ SI; Fig. 5). These two LSC units have also different total gamma-radiation values measured by well-logging (LSC ignimbrite < laccolith). However, this is only weakly supported by the U, Th and K concentrations obtained from laboratory radiation measurements (Fig. 5), where only a negligible increase in Th can be observed. Alternatively, well-logged lower gamma-ray radiation can be explained in terms of primary porosity and natural moisture of the ignimbrite shading the radiation. The overlying TR pyroclastics clearly show higher radiation, mainly due to elevated Th values (Electronic Supplementary Material 2).

In Mi-4, the LSC ignimbrite has lower gamma activity values compared to the laccolith, with the overlying USC ignimbrite showing still higher values. On the contrary, in borehole 2055/85 the LSC ignimbrite yields slightly higher gamma activity than the USC volcanoclastics. Also the USC lava in borehole 2150/87 has gamma activity values comparable to those detected in the USC of borehole 2055/85.

The up to 207 m thick Upper Schönfeld Complex (USC) is represented by a volcanosedimentary succession which, in the Schönfeld area, starts with thick talus deposits (up to $50 \mathrm{~m}$; Figs 2-3). The faintly stratified talus breccias are clast-supported with boulders up to 1.5 $\mathrm{m}$ across, consisting mainly to exclusively of gneiss. The matrix between the boulders is dark and carbonaceous.

The USC volcanosedimentary succession crops out in and east of Schönfeld, north of Ammmelsdorf, on the eastern slope of the Rote Weißeritz Valley near Oberbärenburg, and south of Oberbärenburg (Figs 4c, 9). Small isolated outcrops have been mentioned by Lobin (1986) from the area southwest of Altenberg (Fig. 4c). Numerous boreholes document USC rocks, overlain by TR volcanics north of Ammelsdorf, between Ammelsdorf and Schönfeld, near Oberbärenburg and south of Altenberg, as well as in Mi-4 (Figs 4c, 5). Near the eastern margin of the ATVC, a number of boreholes detected volcanosedimentary units $(\leq 15 \mathrm{~m})$ which may belong to the USC (Fig. 4c). Alternatively, they may represent any volcaniclastic sediment intercalations which have been reported to occur within the TR

\footnotetext{
৫

Fig. 6 Polished rock slabs of LSC and USC volcanic rocks from the Schönfeld-Altenberg Depression Complex: a - USC, top fallout, borehole 2055/85, 101.3 m; b - USC, volcanosedimentary massflow deposit, borehole 2055/85, 121.2 m; c - LSC laccolith, borehole Mi-4, 769.5 m; d - LSC lava, outcrop sample SÖ-05; e - LSC ignimbrite, borehole Mi-4, 916.5 m; f - LSC ignimbrite, borehole 874/68, 28.0 m.
}

succession (Lobin 1986). Also the TR in Mi-4 features these coaly volcaniclastic intercalations (Breiter et al. 2001; Hoffmann et al. 2013).

The USC succession varies strongly between different regions. The Schönfeld area is dominated by volcanosedimentary facies whereas the area south of Altenberg and beyond the German-Czech border is characterized by the predominance of coherent volcanic rocks. In the Schönfeld area, the talus deposits are overlain by mass flow and fluvial deposits of an alluvial fan facies $(18 \mathrm{~m}$ in drilling 2055/85, Fig. 3). Near Oberbärenburg, outcrops of fine-grained alluvial plain deposits mostly consisting of coaly clays to sands represent this early USC stage (Fig. 9). A strong lateral facies variation is documented by the presence of coarse-grained volcaniclastic beds detected in the nearby borehole 111/70 (Fig. 9).

In the Schönfeld region, an alternation of volcaniclastic mass flow deposits and coal seams dominates the USC lithology (Figs 2-3). Within the volcaniclastic deposits, breccias of monomict or polymict composition, and fine tuff layers occur, with thickness ranging between a few $\mathrm{mm}$ and $\sim 1.5 \mathrm{~m}$. The mass flow deposits are generally poorly-sorted, but mostly clast-supported with predominantly angular to sub-rounded clasts (Figs 6b, 7a). Bed thickness ranges between a few $\mathrm{mm}$ and $\sim 1.5 \mathrm{~m}$. Volcanic clasts contain abundant plagioclase and biotite phenocrysts and glassy matrix (replaced by clay minerals). In borehole 2055/85 the SADC succession ends with a $\sim 11$ $\mathrm{m}$ thick clast-supported and well-sorted lapillistone (Fig. $3)$. The plagioclase- and biotite-rich dark-grey unit is interpreted as a proximal fallout (Fig. 6a). From boreholes drilled in the area north of Schönfeld, Lobin (1986) described the Mühlwald Horizon, a $\leq 23 \mathrm{~m}$ thick succession of sediments, which contains reworked USC material. However, in our study we did not recognize this unit.

Apart from the volcaniclastic deposition which probably was related to the formation and explosive destruction of intermediate lava domes, the USC in the Schönfeld area reveals non-volcanogenic sedimentation in the form of coal seams and clast-supported gneiss talus. The highly mature coal seams (thickness: $10 \mathrm{~cm}$ to $8 \mathrm{~m}$; vitrinite reflection values between 2.80 and 5.97; Künstner 1979; Weinlich 1979) show a thin-bedded alternation of coaly claystone and anthracite. This fact and the presence of rounded vitrinite aggregates both point to allochthonous provenance of the plant debris (see also Wolf 1960).

Based on whole-rock geochemical composition we assign volcanic rocks to the USC documented in boreholes south of Altenberg (2018/85, 2150/87, 2153/87), and in Mi-4. The USC rocks in the boreholes south of Altenberg (thickness $\leq 207 \mathrm{~m}$ ) experienced a strong alteration; the relict porphyritic texture suggests a coherent volcanic protolith. The top $21 \mathrm{~m}$ of the SADC sequence in 

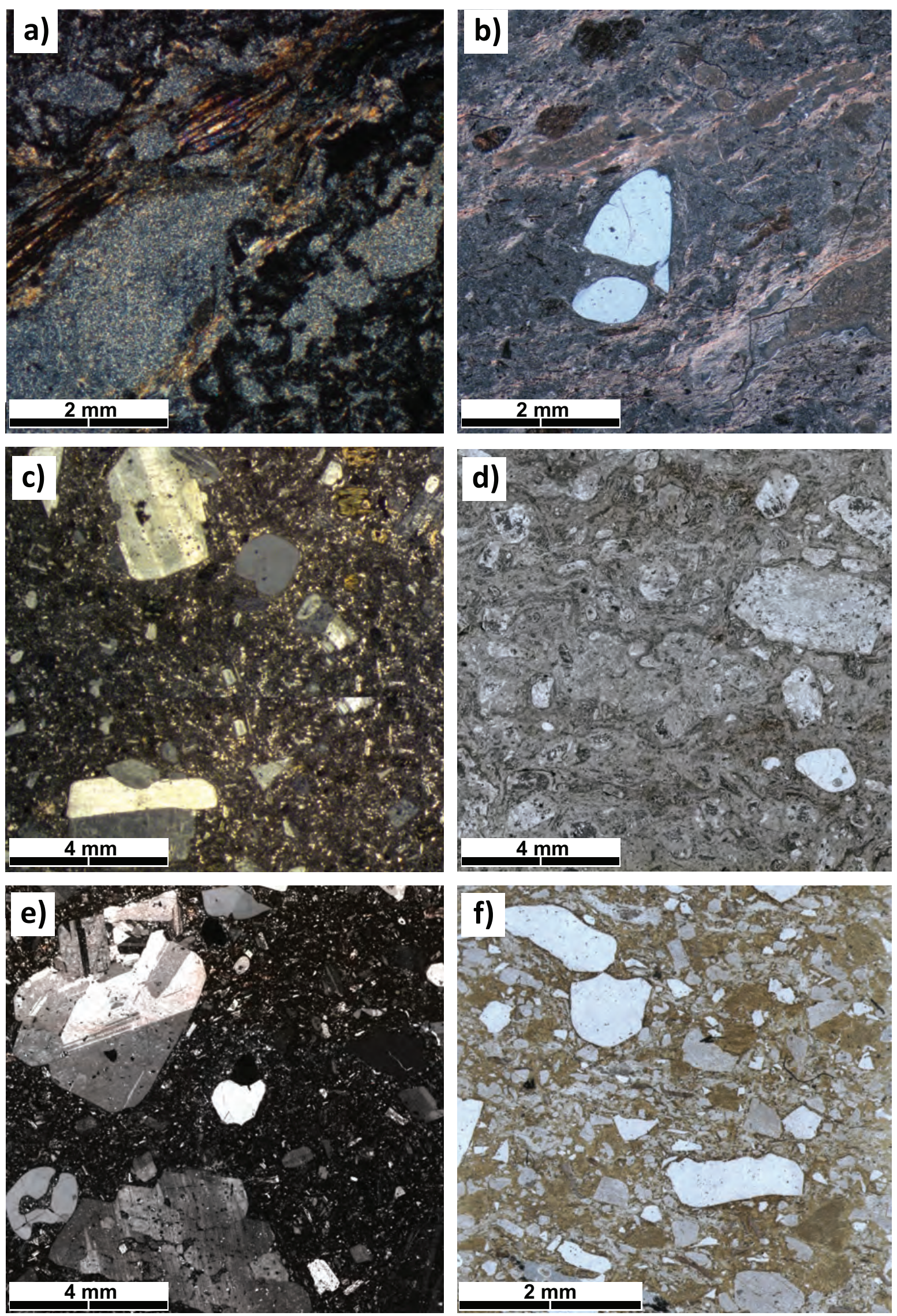
a)

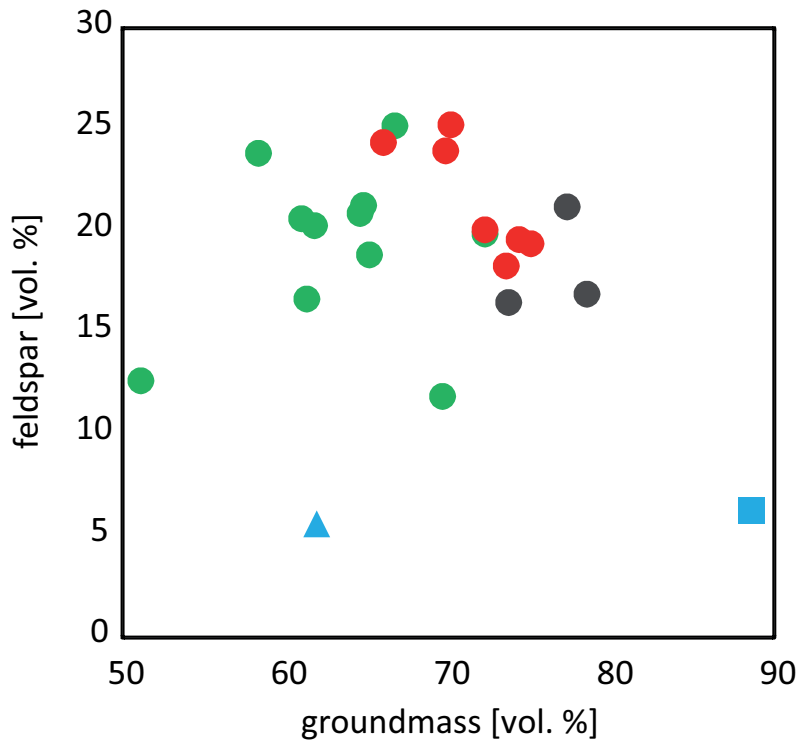

$\triangle$ USC, top fallout

USC, ignimbrite b)

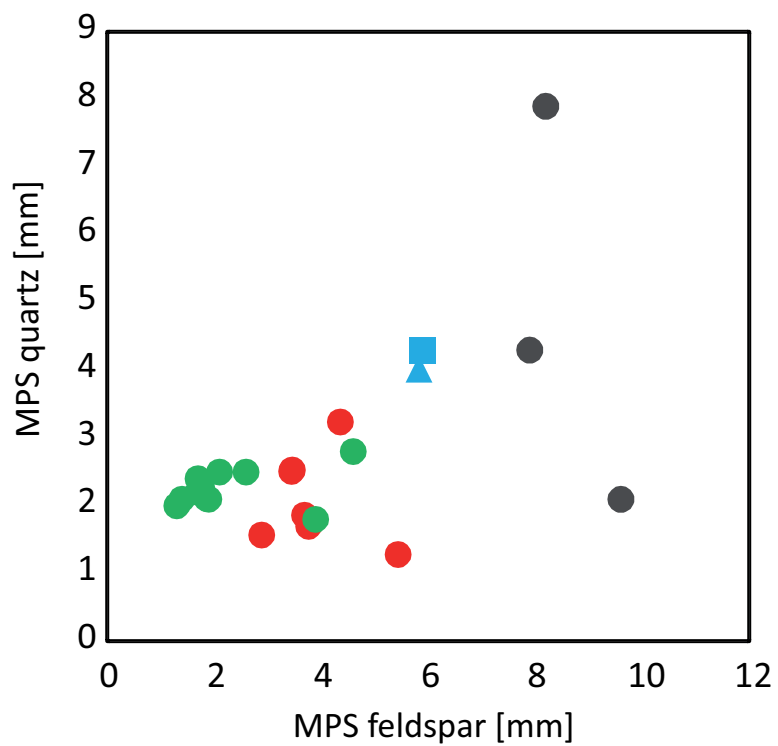

LSC, laccolith

Fig. 8 Modal analyses and grain-size data for the Schönfeld-Altenberg Depression Complex volcanics: a - modal proportions of groundmass vs. feldspars (vol. \%); b - Maximum particle size (MPS) of feldspar and quartz (mm) (Tab. 1).

Mi-4 feature a pumice-rich ignimbrite (Fig. 7b) overlain by a partly reworked fallout deposit.

\subsection{Bulk-rock geochemistry and radiogenic isotope systematics}

Pälchen (1968) and Wetzel (1984) provided the first geochemical data from LSC rocks. The new analytical data are listed in Tabs 2 and 3. The samples cover all volcanic units described above. The two Schönfeld complexes (LSC and USC) differ from each other in alkalinity. The position of the LSC rocks in the TAS diagram (Fig. 10a-b, Le Maitre et al. 2002) with the sum of alkalis (6.0-9.5 wt. \%) separates this group clearly from the less alkaline USC rocks. For rhyolitic and dacitic rocks somewhat elevated contents of Ti (Tab. 2) result in lower $\mathrm{Zr} / \mathrm{Ti}$ ratios and the SADC rocks thus tend to the field of more basic rocks in the $\mathrm{Nb} / \mathrm{Y}$ vs. $\mathrm{Zr} / \mathrm{Ti}$ discrimination diagram (Fig. 10c, Pearce 1996). The presence of quartz

Fig. 7 Photomicrographs of selected LSC and USC volcanic rocks from the Schönfeld-Altenberg Depression Complex (crossed nicols, except for $\mathrm{d}$ and $\mathrm{f}$ taken in plane-polarized light): a - USC volcanosedimentary massflow deposit, borehole 2055/85, $121.2 \mathrm{~m}$; b - USC ignimbrite, borehole Mi-4, $611.2 \mathrm{~m}$; c - LSC laccolith, borehole Mi-4, $730.4 \mathrm{~m}$; d - LSC subvolcanic dacite, outcrop sample SÖ-07; e - LSC coarse-grained ignimbrite, sample SÖ-22 from abandoned quarry in Hermsdorf; f - LSC ignimbrite, borehole 874/68, 109.8 m. in LSC ignimbrites and relatively high proportions of Kfeldspar correspond well with the position of the studied rocks in the TAS diagram.

The lower part of the LSC, consisting of ignimbrites, is chemically more differentiated with higher silica (68.8-73.8 wt. \%, except SÖ-22A: $\mathrm{SiO}_{2}=65.9$ wt. \%), and lower $\mathrm{TiO}_{2}\left(0.20-0.33\right.$ wt. \%, except SÖ-22A: $\mathrm{TiO}_{2}$ $=0.71 \mathrm{wt} . \%$ ) compared with the overlying massive LSC dacites to trachydacites $\left(\mathrm{SiO}_{2}=64.5-68.6 \mathrm{wt}\right.$. \%; $\mathrm{TiO}_{2}=$ $0.5-0.7$ wt. \%). The LSC ignimbrites have a more pronounced negative Eu anomaly $\left(\mathrm{Eu} / \mathrm{Eu}^{*}=0.58-0.72\right.$, one sample at 0.83$)$ compared to the LSC dacites $\left(\mathrm{Eu} / \mathrm{Eu}^{*}=\right.$ 0.74-0.91), reflecting a more differentiated character or a different magmatic source of the ignimbrites. The coherent dacites are characterized by higher total REE contents $(\Sigma \mathrm{REE}=165-210 \mathrm{ppm})$ and steeper chondrite-normalized REE patterns $\left(\mathrm{La}_{\mathrm{N}} / \mathrm{Yb}_{\mathrm{N}}=17.4-20.7\right.$, normalization after Boynton 1984; Fig. 11a) compared to the LSC ignimbrites $\left(\Sigma \mathrm{REE}=85-130 \mathrm{ppm}, \mathrm{La}_{\mathrm{N}} / \mathrm{Yb}_{\mathrm{N}}=7.5-11\right)$.

Most USC volcanics display subtle compositional variations. Only negligible differences were observed between lavas and mass-flow deposits, suggesting that the mass-flow deposits were derived from the lavas and are dominated by lava clasts (as observed in thin-sections) with a little admixture of a non-volcanic material (also scarce organic fragments found in thin-sections). Most USC rocks plot in the dacite field in the TAS diagram (Fig. 10b) with much lower alkalis (4.5-7 wt. 
$\%)$ compared to the LSC. The only exception is the late rhyolitic fall-out deposit (Figs 3,6a) with high silica and variable contents of alkalis. The more differentiated character of this unit is also reflected in lower $\mathrm{TiO}_{2}$ content (0.23-0.30 wt. \%) contrasting with the significantly higher $\mathrm{TiO}_{2}$ contents of the other members of the USC (0.58-0.81 wt. \%).

In the spiderplots normalized by the average lower crustal composition (Taylor and McLennan 1995), the USC rocks are characterized by a very strong negative
Sr anomaly (Fig. 11b), which is more pronounced in the case of the fallout deposit. The lavas, ignimbrites and mass-flow deposits of the USC have the highest REE contents $(\Sigma \mathrm{REE}=174-305 \mathrm{ppm})$, but the patterns evolve parallel to those of the LSC lavas $\left(\mathrm{La}_{\mathrm{N}} / \mathrm{Yb}_{\mathrm{N}}\right.$ = 15.9-19.7). They feature a negligible or absent Eu anomaly, which can be even slightly positive $\left(\mathrm{Eu} / \mathrm{Eu}^{*}=\right.$ 0.7-1.16, Fig. 11a).

The composition of SADC rocks can be compared with experimental melts of various possible crustal sources (Patiño Douce 1999; Fig. 12). The wide ranges of $\mathrm{Al}_{2} \mathrm{O}_{3}+\mathrm{FeO}_{\mathrm{t}}+\mathrm{MgO}+\mathrm{TiO}_{2}$ values combined with generally low $\mathrm{Al}_{2} \mathrm{O}_{3}$ concentrations suggest the magmas of the SADC were most likely derived by partial melting of amphibolitic and greywacke source.

The $\mathrm{Sr}$ and $\mathrm{Nd}$ isotopic data of four whole-rock samples (Mi-4/614 - USC rhyolitic ignimbrite, Mi-4/916 - LSC dacitic ignimbrite, Mi-4/814 and SÖ-01 - both (trachy) dacitic subvolcanic units) are listed in Tab. 4. The Schönfeld volcanic rocks erupted at $\sim 325$ Ma (Hoffmann et al. 2013), which is also the age used for calculation of the initial ratios $\left({ }^{87} \mathrm{Sr} /{ }^{86} \mathrm{Sr}_{\mathrm{i}} ;{ }^{143} \mathrm{Nd} /{ }^{144} \mathrm{Nd}_{\mathrm{i}}\right)$ and the two-stage model age $\left(\mathrm{T}^{\mathrm{Nd}}{ }_{\mathrm{DMI}}\right)$. Despite a large difference in concentrations of $\mathrm{Sr}$ and Nd ( 70-443 ppm Sr; 21-53 ppm Nd, respectively), the $\mathrm{Rb} / \mathrm{Sr}$ and $\mathrm{Sm} / \mathrm{Nd}$ ranges are limited $(0.4-3.3$ and $0.18-0.20$, respectively). Initial ratios are relatively uniform $\left({ }^{87} \mathrm{Sr} /{ }^{86} \mathrm{Sr}_{325}=\sim 0.7056\right.$ to $0.7063,{ }^{143} \mathrm{Nd} /{ }^{144} \mathrm{Nd}_{325}=$ 0.51205-0.51210; Fig. 13). The $\varepsilon \mathrm{Nd}_{325}$ values range from -2.4 to $-3.3\left(\mathrm{~T}_{\mathrm{DMII}}^{\mathrm{Nd}}=1.2\right.$ to $1.3 \mathrm{Ga})$.

Fig. 9 Generalized stratigraphic profile of the NE slope of the Rote Weißeritz Valley near Oberbärenburg (a), and section of borehole 111/70 nearby (b), depicting the USC and under-/overlying units. c - Geological sketch map of the area. 


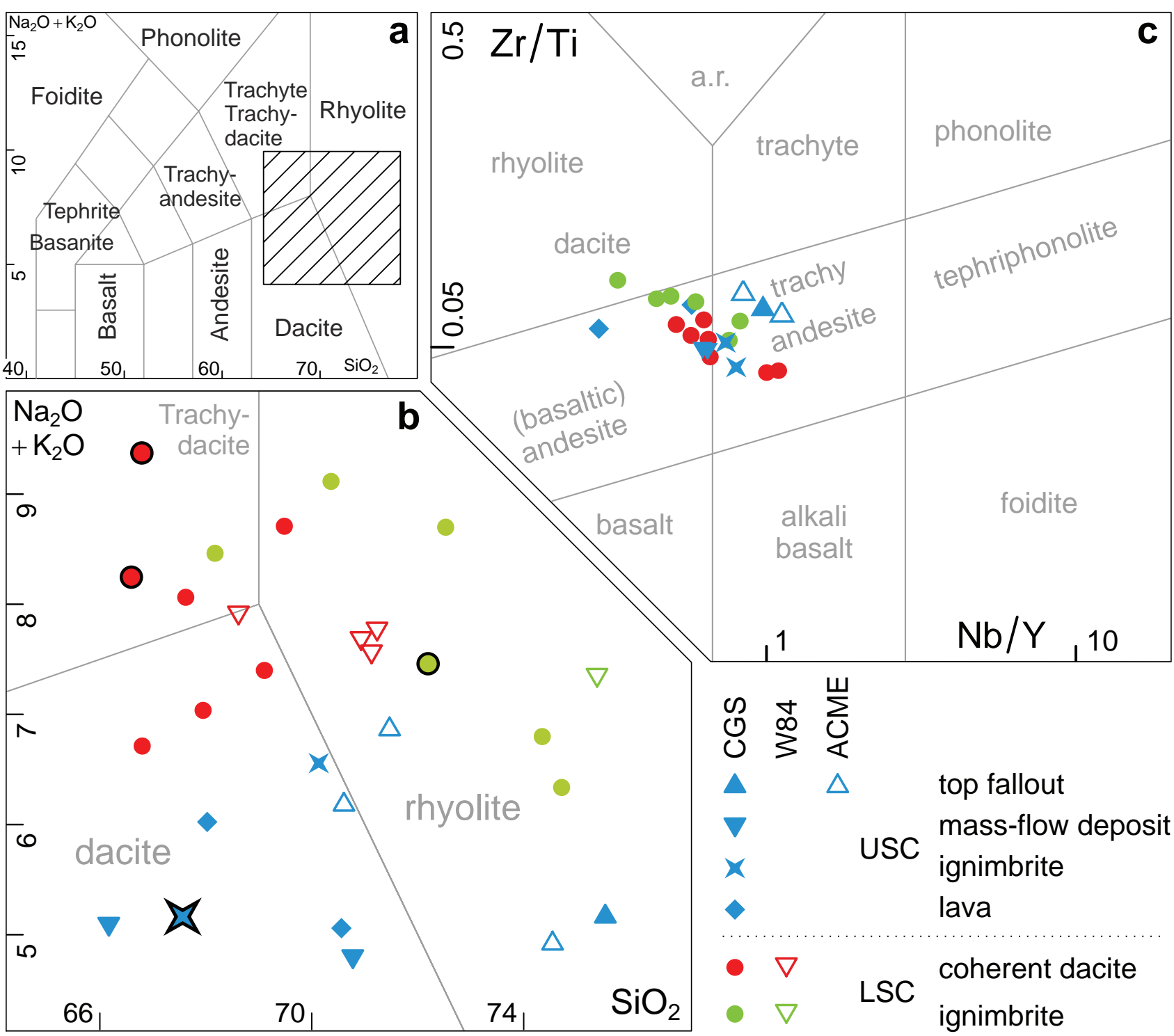

Fig. 10a - Total alkalis-silica (TAS) classification diagram for the Schönfeld-Altenberg Depression Complex volcanics (Le Maitre et al. 2002) with a close-up in (b) where samples used for isotopic analyses are outlined in black; c $-\mathrm{Zr} / \mathrm{Ti}$ vs. Nb/Y classification plot (Pearce 1996). Data from Wetzel (1984) and this work (Tabs 2-3).

\section{Discussion and scenario of volcanosedimentary evolution}

Volcanosedimentary facies analysis and evaluation of geochemical data reveal that the SADC evolution involved three main stages (Fig. 14), presumably during the Late Mississippian (c. $326 \mathrm{Ma}$ ). The peak of deformation and metamorphism in the underlying basement of the eastern Erzgebirge is poorly dated at c. 330 Ma (Romer and Hahne 2010). This implies a relatively rapid uplift and partial erosion of the metamorphic nappes.

Formation of the basin possibly started with extension along NE-SW oriented lineaments (Fig. 14a; Lobin 1986). This orientation contrasts with the overall shape of the ATVC, and with regional NW-SE trending faults such as the Elbe and the Brandov-Olbernhau lineaments. However, it matches the orientation of the extended Berggießhübel-Sayda dyke swarm exposed in close northern and eastern vicinity of the ATVC (Wetzel 1984; Winter et al. 2008 and references therein). Grain size and palaeocurrent analysis indicate sediment transport towards the south (SPES), into alluvial fans near Schönfeld and into the alluvial plains near Hermsdorf as well as further south (Lobin 1986). The original extent of the SPES may have been larger; however, subsequent tectonic activity and extensive erosion resulted in the patchy out- and subcrop distribution (Fig. 4a). 
The crystal-rich, fine-grained LSC ignimbrites, detected in boreholes 2055/85 and Mi-4, and in the Hermsdorf area, with a present-day minimum areal extent of $c .35$ $\mathrm{km}^{2}$, are the product of a major explosive eruption. The presumably sub-Plinian event led to the accumulation of thick, massive and weakly welded pyroclastic flow deposits. Its initial phase was characterized by an alternation of pyroclastic deposition and sedimentation of non-volcanic sediments ('basal tuff' in Fig. 4b). Based on the thickness distribution and the location of known LSC subvolcanic
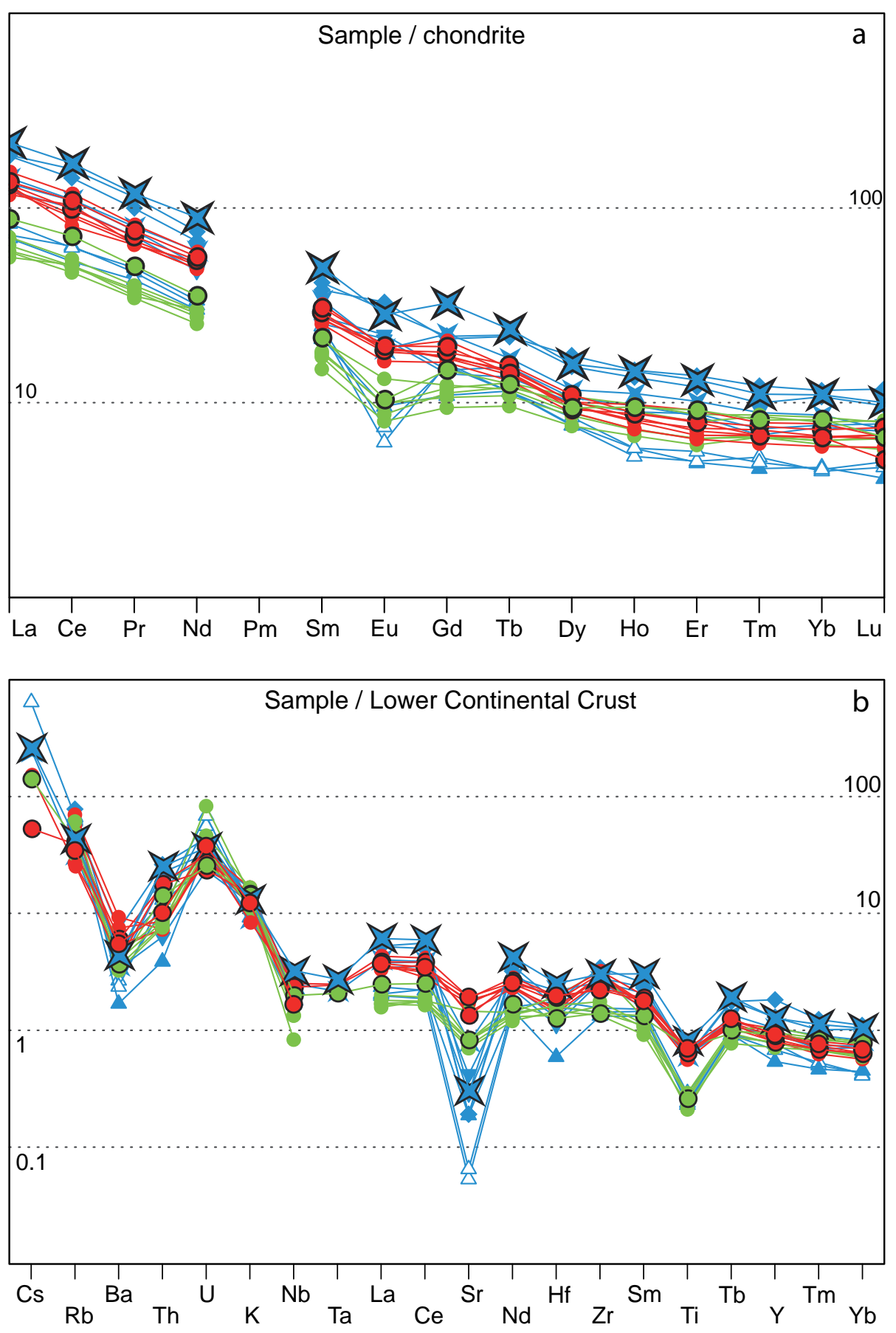

bodies, an important vent possibly was located east of Hermsdorf (Fig. 14b). The deposition of LSC ignimbrites culminated by coarse-grained ignimbrite in this area. The presence of the porphyritic laccolith in Mi-4 suggests that another conduit system was located in the south.

The presence of paleo-talus gneiss deposits at the base of the USC in the Schönfeld area indicates prominent tectonic activity that took place at the onset of USC deposition. Presumably normal faulting lead to the formation of foot wall scarps exposing metamorphic basement.

During the USC formation, the Ammelsdorf-Schönfeld area presumably was a volcaniclastic apron of a major dacitic lava dome complex located south of Altenberg. Some pyroclastic flows also reached the Mi-4 area in the south. The volcaniclastic apron accumulated mass-flow deposits, alternating with coal-rich sediments. Volcaniclastic mass flow deposits alternating with coal layers are a frequent feature of Carboniferous-Permian basins throughout Europe (e.g. Dill 1987, Reichel and Schneider 2012). The USC mass-flow deposits are dominated by angular to sub-rounded clasts of lava, an observation also supported by their whole-rock geochemical compositions. The debrites therefore most likely represent monomict lava-derived lahars or block-and-ash flow deposits. Probably, the USC block-andash flows moved through forests causing wild fires and producing large amounts of charcoal (see accounts on subrecent volcanic centres e.g. by Hudspith et al. 2010, and experimental studies e.g. by Sawada et al. 2000). Later alluvial reworking of the block-and-ash flow deposits par-

Fig. 11a - The REE patterns of Schönfeld-Altenberg Depression Complex volcanics, normalized to chondrite (Boynton 1984), b - Trace-element pattern of SADC volcanics, normalized to lower continental crust (Taylor and McLennan 1995). Symbols correspond to Fig. 10, samples used for isotopic analyses have black outlines. 


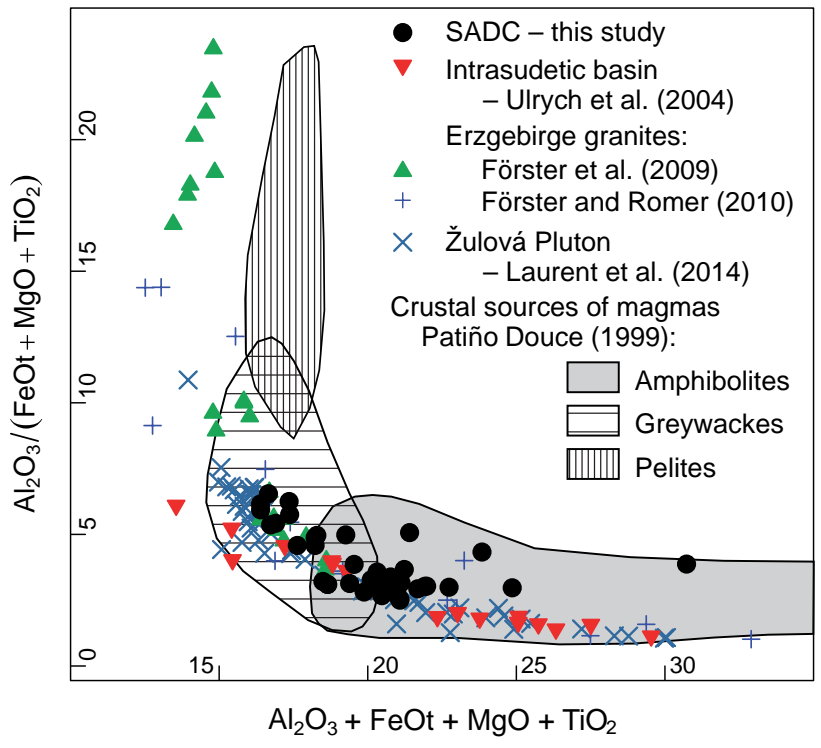

Fig. 12 Binary plot of $\mathrm{Al}_{2} \mathrm{O}_{3}+\mathrm{FeO}_{\mathrm{t}}+\mathrm{MgO}+\mathrm{TiO}_{2}$ vs. $\mathrm{Al}_{2} \mathrm{O}_{3} /\left(\mathrm{FeO}_{\mathrm{t}}+\right.$ $\mathrm{MgO}+\mathrm{TiO}_{2}$ ) for Schönfeld-Altenberg Depression Complex volcanic and volcaniclastic rocks and other post-Variscan magmatic rocks compared to experimental melts derived from various possible crustal sources (Patiño Douce 1999).

tially separated dense volcanic from less dense coal fragments. The cause of the apparent high maturity of the coal seams in Schönfeld (Wolf 1960; Lobin 1986 and references therein) remains unclear.

Today's distribution of SPES, USC and LSC units does not reveal any significant shift of basins during the SADC

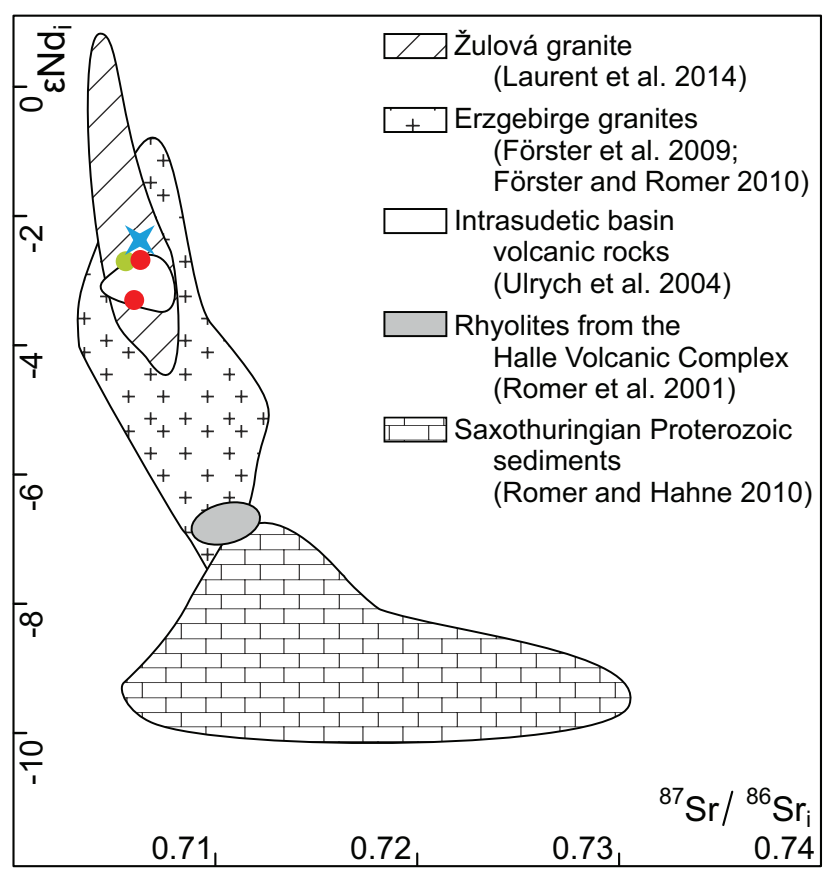

Fig. 13 The ${ }^{87} \mathrm{Sr} /{ }^{86} \mathrm{Sr}_{\mathrm{i}}$ vs. $\varepsilon \mathrm{Nd}_{\mathrm{i}}$ plot of the studied volcanic rocks (symbols as in Fig. 10) compared with data for post-collisional igneous rocks in Central Europe and Proterozoic Saxothuringian metasediments. evolution. As already pointed out by Lobin (1986) the SADC units experienced considerable erosion.

Evolution of the chemical composition within the LSC (up-sequence decrease in $\mathrm{SiO}_{2}$, increase in $\mathrm{TiO}_{2}$, $\mathrm{Cr}, \mathrm{V}$ ) and weakening of the negative Eu anomaly would suggest gradual exhausting of a common zoned magma chamber (e.g., Blake 1981; Bacon and Druitt 1988). If so, an upwards decrease in total REE contents and LREE/ HREE ratios (i.e. increasing $\mathrm{REE}$ and LREE/HREE with increasing differentiation) would be expected, but the opposite trend is observed in the succession.

The USC differs from the LSC generally in lower alkalinity, and a strong negative $\mathrm{Sr}$ anomaly in the average lower-crust normalized spiderplots. Based on the chemical composition, the USC rocks can be subdivided into two groups. Lavas, mass-flow deposits and ignimbrites have relatively uniform composition with high $\Sigma$ REE and no Eu anomaly. The top fallout differs from the rest of the USC suite not only in higher silica and more pronounced depletion in Sr, but also in stronger negative Eu anomaly $\left(\mathrm{Eu} / \mathrm{Eu}^{*}=0.3-0.6\right.$; Fig. 11a), low $\mathrm{TiO}_{2}, \mathrm{Zr}$ and also Cr.

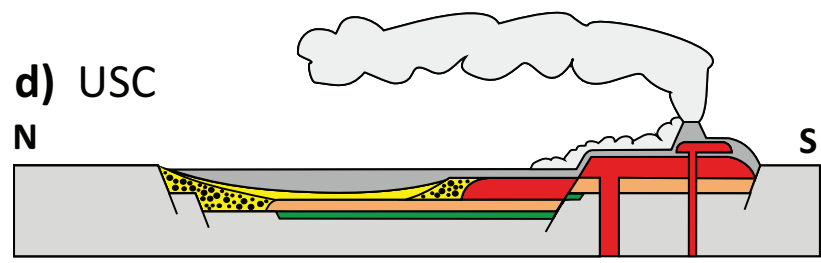

\section{c) USC}

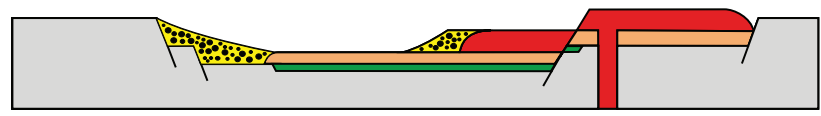

\section{b) LSC}

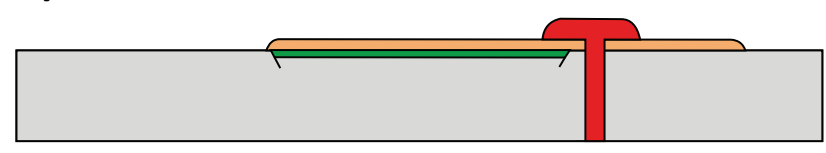

\section{a) SPES}

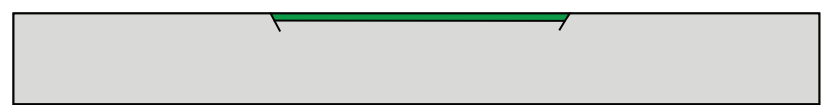

Fig. 14 Tentative evolution of the Schönfeld-Altenberg Depression Complex depicted in schematic N-S-oriented sections: a - sedimentation of the SPES; $\mathbf{b}$ - eruption of LSC ignimbrites and lava complexes; c - tectonic activity and sedimentation of talus at the onset of the USC formation; d - USC eruptions producing ignimbrites, lavas, lava-derived mass-flows and fall-out deposits. 
The $\varepsilon^{\mathrm{Nd}}{ }_{325}$ for four samples of -2.4 to -3.3 are significantly higher (i.e. more primitive) than Saxothuringian sediments (-7.0 to -11.6; Romer and Hahne 2010), and also unaltered rhyolites from comparable Halle Volcanic Complex of similar age ( $\varepsilon^{\mathrm{Nd}}=-6.7$ to -7.0 ; Romer et al. 2001). On the other hand, $\mathrm{Sr}$ and $\mathrm{Nd}$ isotopic compositions resemble the nearby Erzgebirge granites (Förster et al. 2009; Förster and Romer 2010). Interestingly, the isotopic fingerprint is also close to more distant PermoCarboniferous magmatic products such as Intra-Sudetic Basin volcanic rocks or the Žulová granite (Fig. 12; Ulrych et al. 2004; Laurent et al. 2014).

The new two-stage Nd model ages (1.2-1.3 Ga) are close to those calculated for the Erzgebirge granites ( 1.3-1.5 Ga; Förster et al. 2009), but are younger than those of rhyolites from the Halle Volcanic Complex ( $\mathrm{T}^{\mathrm{Nd}-}$ DмII $\sim 1.6$ Ga, Romer et al. 2001) and Saxothuringian sediments derived from mainly Laurussian terranes $\left(\mathrm{T}^{\mathrm{Nd}}{ }_{\text {DMII }}\right.$ $\sim 1.8 \mathrm{Ga}$; Romer and Hahne 2010). Almost identical $\mathrm{T}^{\mathrm{Nd}}$ ages were reported for the Intra-Sudetic volcanics $\left(\mathrm{T}_{\text {DMII }}^{\mathrm{NM}} \sim 1.3 \mathrm{Ga}\right.$, Ulrych et al. 2004) and granites from the post-orogenic Žulová Pluton in Silesia $\left(\mathrm{T}_{\text {DMII }}^{\mathrm{Nd}} \sim 1.3\right.$ Ga, Laurent et al. 2014). Comparable model ages from the eastern part of the Saxothuringian Zone indicate a common protolith with an average Mesoproterozoic crustal residence. The model ages also partly overlap with modified Re-depletion ages $\left(\mathrm{T}_{\mathrm{RDII}}\right)$, reported for peridotite xenoliths from the Saxothuringian part of the Bohemian Massif (1.0-1.2 Ga; Kochergina et al. 2016). This indicates common evolution of the Saxothuringian crust with the adjoining subcontinental lithospheric mantle.

\section{Conclusions}

- The Schönfeld-Altenberg Depression Complex (SADC) represents the oldest post-orogenic volcanosedimentary complex in the Variscan Bohemian Massif.

- The entire complex can be subdivided into three units: Schönfeld-pre-eruptive sediments (SPES), Lower Schönfeld Complex (LSC) and Upper Schönfeld Complex (USC).

- The volcanic activity consisted of ignimbrite-forming eruptions, lava effusions with associated block-and-ash flows, and subvolcanic magma emplacement.

- The volcaniclastic material was transported in the form of pyroclastic flows, mass-flows and ash-clouds depositing fallouts.

- Syn-volcanic tectonic activity played an important role during evolution of the SADC, as documented by the presence of coarse-grained sedimentary layers.

- Geochemical properties clearly set apart the less alkaline USC from the more alkaline LSC units.
- The limited $\mathrm{Sr}-\mathrm{Nd}$ isotopic data are homogeneous and relatively primitive $\left(\varepsilon^{\mathrm{Nd}}\right.$ ranging from -2.4 to -3.3 ).

- The two-stage Depleted Mantle Nd model ages of the four studied samples (1.2-1.3 Ga) resemble those from Erzgebirge granites and elsewhere in the Saxothuringian Zone, and volcanic rocks within the Intra-Sudetic Basin. This indicates a similar source of magmas (i.e. a Mesoproterozoic lithosphere).

Acknowledgements. Analytical work at the Czech Geological Survey in this study was carried out within the framework of the project "Reassessment of the groundwater resources" supported by the EU (Operational Program for Environment), the State Environment Fund of the Czech Republic and the Czech Ministry of Environment. We thank the WISMUT GmbH, Chemnitz, for facilitating access and sample permission of their drill cores and related documents. The Czech-German cooperation in research on Late Paleozoic volcanic systems runs within the frame of the VENTS programme (http://www.vents.ing.uni.wroc.pl). The manuscript benefited from constructive comments by Reimar Seltmann and an anonymous reviewer as well as from careful editorial handling by Miroslav Štemprok and Vojtěch Janoušek.

Electronic supplementary material. The list of samples and boreholes used for analytical work, petrophysical data, archive analytical data from Wetzel (1984) and measured concentrations of trace elements in international standards are available online at the Journal web site (http://dx.doi.org/10.3190/jgeosci.219).

\section{References}

Ackerman L, Haluzová E, Creaser Ra, Pašava J, Veselovský F, Breiter K, Erban V, Drábek M (in print) Temporal evolution of mineralization events in the Bohemian Massif inferred from Re-Os geochronology of molybdenite. Miner Depos, doi: 10.1007/s00126016-0685-5

BACON CR, DRUITT TH (1988) Compositional evolution of the zoned calcalkaline magma chamber of Mount Mazama, Crater Lake, Oregon. Contrib Mineral Petrol 98: 224-256

Beск R (1887) Geologische Karte, Section Nassau, Blatt 118, Maßstab 1:25 000, $1^{\text {st }}$ edition. W. Engelmann, Leipzig

BeneK R (1991) Aspekte einer Volumenbilanz paläovulkanischer Förderprodukte - Beispiel Teplice-Rhyolith (Ostdeutschland). Z geol Wiss 19: 379-389

BlaKe S (1981) Eruptions from zoned magma chambers. J Geol Soc, London 138: 281-287 
Boynton WV (1984) Cosmochemistry of the rare earth elements: meteorite studies. In: Henderson P (ed) Rare Earth Element Geochemistry. Elsevier, Amsterdam-New York, pp 63-114

Breiter K, Novák JK, Chlupáčová M (2001) Chemical evolution of volcanic rocks in the Altenberg-Teplice caldera (Eastern Krušné Hory Mts., Czech Republic, Germany). Geolines 13: 17-22

Breiter K, Svojtka M, Ackerman L, Švecová K (2012) Trace element composition of quartz from the Variscan Altenberg-Teplice caldera (Krušné hory/Erzgebirge Mts, Czech Republic/Germany): insights into the volcanoplutonic complex evolution. Chem Geol 326: 36-50

Breiter K, Gardenová N, Vaculovič T, Kanický V (2013) Topaz as an important host for Ge in granites and greisens. Mineral Mag 77: 403-417

DALMER K (1890) Erläuterungen zur geologischen Specialkarte des Königsreiches Sachsen, Section AltenbergZinnwald. Commision bei W. Engelmann, Leipzig, pp $1-110$

Dempírová L, Šikl J, KaŠičKová R, Zoulková V, KŘíbek $B$ (2010) The evaluation of precision and relative error of the main components of silicate analyses in Central Laboratory of the Czech Geological Survey. Zpr geol výzk za r 2009: 326-330 (in Czech)

DiLl H (1987) Environmental and diagenetic analyses of Lower Permian epiclastic and pyroclastic fan deposits - their role for coal formation and uranium metallogeny in the Stockheim Trough (F.R.G.). Sedim Geol 52: 1-26

EISENREICH M (ed) (1985) Evaluation of the structural borehole Mi-4. Unpublished report, Czech Geological Survey, Prague, pp 1-11

FÖrster H-J, Romer RL (2010) Carboniferous magmatism. In: Linnemann U, Romer R (eds) Pre-Mesozoic Geology of Saxo-Thuringia: From the Cadomian Active Margin to the Variscan Orogen. Schweizerbart, Stuttgart, pp 287-308

Förster H-J, Tischendorf G, Trumbull RB, Gottesmann B (1999) Late-collisional granites in the Variscan Erzgebirge, Germany. J Petrol 40: 1613-1645

Förster H-J, Rhede D, Hecht L (2008) Chemical composition of radioactive accessory minerals: implications for the evolution, alteration, age, and uranium fertility of the Fichtelgebirge granites (NE Bavaria, Germany). Neu Jb Mineral, Abh 185: 161-182

Förster H-J, Romer RL, Gottesmann B, Tischendorf G, RHEDE D (2009) Are the granites of the Aue-Schwarzenberg Zone (Erzgebirge, Germany) a major source for metalliferous ore deposits? A geochemical, $\mathrm{Sr}-\mathrm{Nd}-\mathrm{Pb}$ isotopic, and geochronological study. Neu Jb Mineral, Abh 186: 163-184

GeINITz HB (1856) Die Steinkohlen des Königreichs Sachsen. Erste Abtheilung: Geognostische Darstellung der Steinkohlenformation in Sachsen mit besonderer Berücksich- tigung des Rothliegenden. Engelmann, Leipzig, pp 1-91 Gothan W (1932) Die Altersstellung des Karbons von Flöha i. Sa. im Karbonprofil auf Grund der Flora. Abh Sächs Geol Landesamts 12: 1-16

Hoffmann U, Breitkreuz C, Breiter K, Sergeev S, Stanek K, Tichomirowa M (2013) Carboniferous-Permian volcanic evolution in Central Europe - U/Pb ages of volcanic rocks in Saxony (Germany) and northern Bohemia (Czech Republic). Int J Earth Sci 102: 73-99

Hoth K, Wasternack J, Berger HJ, Breiter K, Mlčoch B, Schovánek P (1995) Geologische Karte Erzgebirge/ Vogtland 1 : 100 000. Sächsisches Landesamt für Umwelt und Geologie, Freiberg

Hudspith V, Scott AC, Wilson CJN, Collinson ME (2010) Charring of woods by volcanic processes: an example from the Taupo ignimbrite, New Zealand. Palaeogeogr Palaeoclimatol Palaeoecol 291: 40-51

Jacobsen SB, Wasserburg GJ (1980) Sm-Nd isotopic evolution of chondrites. Earth Planet Sci Lett 50: 139-155

Jiránek J, Kříbek B, Mlčoch B, Procházka J, Schovánek P, Schovánková D, Schulmann K, Šebesta J, Šimưnek Z, ŠTemproK M (1987) Complex geological evaluation of the Teplice Rhyolite. Unpublished report, Czech Geological Survey, pp 1-114 (in Czech)

Jochum KP, Nohl U, Herwig K, Lammel E, Stoll B, HofMANN AW (2005) GeoReM: a new geochemical database for reference materials and isotopic standards. Geost Geoanal Res 29: 333-338

Johan Z, Strnad L, Johan V (2012) Evolution of the Cínovec (Zinnwald) Granite Cupola, Czech Republic: composition of feldspars and micas, a clue to the origin of W, Sn mineralization. Canad Mineral 50: 1131-1148

Kochergina YV, Ackerman L, Erban V, Matusiak-Malek M, Puziewicz J, Halodová P, Špaček P, Trubač J, Magna $\mathrm{T}$ (2016) Rhenium-osmium isotopes in pervasively metasomatized mantle xenoliths from the Bohemian Massif and implications for the reliability of Os model ages. Chem Geol 430: 90-107

Kroner U, Romer RL (2010) The Saxo-Thuringian Zone - tip of the Armorican spur and part of the Gondwana plate. In: Linnemann U, Romer R (eds) Pre-Mesozoic Geology of Saxo-Thuringia - From the Cadomian Active Margin to the Variscan Orogen. Schweizerbart, Stuttgart, pp 371-394

Kroner U, Hahn T, Romer RL, Linnemann U (2007) The Variscan orogeny in the Saxo-Thuringian Zone - heterogeneous overprint of Cadomian/Paleozoic peri-Gondwana crust. In: Linnemann U, Nance DR, Kraft P, Zulauf G (eds) The Evolution of the Rheic Ocean: From Avalonian-Cadomian active margin to Alleghenian-Variscan collision. Geological Society of America Special Papers 423: $153-172$

KüNSTNER E (1979) Vergleichende Inkohlungsuntersuchungen unter besonderer Berücksichtigung mikrophotome- 
trischer Reflexionsmessungen an Kohlen, Brandschiefern und kohlehaltigem Nebengestein. Freiberger Forsch $\mathrm{H}$ C 287: 1-115

Laurent A, Janoušek V, Magna T, Schulmann K, Míková J (2014) Petrogenesis and geochronology of a post-orogenic calc-alkaline magmatic association: the Žulová Pluton, Bohemian Massif. J Geosci 59: 415-440

Le Maitre RW(ed), Streckeisen A, Zanettin B, Le Bas MJ, Bonin B, Bateman P, Bellieni G, Dudek A, Efremova S, Keller J, Lameyre J, Sabine PA, Schmid R, Sørensen H, Wooley AR (2002) Igneous Rocks. A Classification and Glossary of Terms. Recommendations of the International Union of Geological Sciences Subcommission on the Systematics of Igneous Rocks. $2^{\text {nd }}$ Edition, Cambridge University Press, Cambridge-New York, pp 1-193

Liew TC, Hofmann AW (1988) Precambrian crustal components, plutonic associations, plate environment of the Hercynian Fold Belt of Central Europe: indications from a Nd and Sr isotopic study. Contrib Mineral Petrol 98: $129-138$

LoBIN M (1986) Aufbau und Entwicklung des Permosiles im östlichen und mittleren Erzgebirge. Unpublished PhD thesis, Bergakademie Freiberg, pp 1-63

Lugmair GW, Marti K (1978) Lunar initial ${ }^{143} \mathrm{Nd} /{ }^{144} \mathrm{Nd}$ : differential evolution line of the lunar crust and mantle. Earth Planet Sci Lett 39: 349-357

MANLEY CR, FinK JH (1987) Internal textures of rhyolite flows as revealed by research drilling. Geology 15 : 549-552

MLČOCH B (1989) Geological map ČSSR 1:25 000, sheet 02-314 Litvínov. Czech Geological Survey, Prague

MlČoch B, SkÁcelová Z (2010) Geometry of the AltenbergTeplice Caldera revealed by the borehole and seismic data in its Czech part. J Geosci 55: 217-229

Moesta G (1929) Brüche und Porphyreffusionen im östlichen Erzgebirge. Z Dtsch geol Gesell 80: 343-408

Müller A, Seltmann R (2002) Plagioclase-mantled K-feldspar in the Carboniferous porphyric microgranite of Altenberg-Frauenstein, Eastern Erzgebirge/Krušné Hory. Bull Geol Soc Finland 74: 53-79

Müller A, Breiter K, Seltmann R, Pécskay Z (2005) Quartz and feldspar zoning in the eastern Erzgebirge volcano-plutonic complex (Germany, Czech Republic): evidence of multiple magma mixing. Lithos 80 : 201-227

Pälchen W (1968) Zur Geochemie und Petrologie der postorogenen variszischen Magmatite des sächsischen Osterzgebirges. Unpublished $\mathrm{PhD}$ thesis, Bergakademie Freiberg, pp 1-142

Pälchen W, Ossenkopf P (1967) Über das relative Alter des Schellerhauuer Granitmassivs und seiner Varietäten. Ber Dtsch Gesell geol Wiss B 12: 359-371

Patiño Douce AE (1999) What do experiments tell us about the relative contributions of crust and mantle to the origin of granitic magmas? In: Castro A, Fernandez C, VignERESSE JL (eds) Understanding Granites: Integrating New and Classical Techniques. Geological Society, London, Special Publications 168: 55-75

Pearce (1996) A user's guide to basalt discrimination diagrams. In: Wyman DA (ed) Trace Element Geochemistry of Volcanic Rocks: Applications for Massive Sulphide Exploration. Geological Association of Canada, Short Course Notes 12: 79-113

Pin C, Zalduegui JFS (1997) Sequential separation of light rare-earth elements, thorium and uranium by miniaturized extraction chromatography: application to isotopic analyses of silicate rocks. Anal Chim Acta 339: 79-89

Pin C, Gannoun A, Dupont A (2014) Rapid, simultaneous separation of $\mathrm{Sr}, \mathrm{Pb}$, and Nd by extraction chromatography prior to isotope ratios determination by TIMS and MC-ICP-MS. J Anal At Spectrom 29: 1858-1870

Reichel W, Schneider JW (2012) Rotliegend im DöhlenBecken. SDGG 61: 589 - 625

Romer RL, HAhNe K (2010) Life of the Rheic Ocean: scrolling through the shale record. Gondwana Res 17: 236-253

Romer RL, Förster H-J, BreitKreuz C (2001) Intracontinental extensional magmatism with a subduction fingerprint: the Late Carboniferous Halle Volcanic Complex (Germany). Contrib Mineral Petrol 141: 201-221

Romer RL, Thomas R, Stein HJ, Rhede D (2007) Dating multiply overprinted Sn-mineralized granites - examples from the Erzgebirge, Germany. Miner Depos 42: 337-359

Romer RL, Förster H-J, ŠtemproK M (2010) Age constraints for the late-Variscan magmatism in the Altenberg-Teplice Caldera (Eastern Erzgebirge/Krušné hory). Neu Jb Mineral, Abh 187: 289-305

Sawada Y, Sampei Y, Hyodo M, Yagami T, Fukue M (2000) Estimation of emplacement temperatures of pyroclastic flows using $\mathrm{H} / \mathrm{C}$ ratios of carbonized wood. J Volcanol Geotherm Res 104: 1-20

Schneider JW, Hoth K, Gaitzsch BG, Berger H-J, SteinBorn H, Walter H, Zeidler MK (2005) Carboniferous stratigraphy and development of the Erzgebirge Basin, East Germany. Z Dtsch Ges Geowiss 156: 431-466

Schulmann K, Lexa O, Janoušek V, Lardeaux JM, Edel JB (2014) Anatomy of a diffuse cryptic suture zone: an example from the Bohemian Massif, European Variscides. Geology 42: 275-278

Seifert T, Atanasova P, Gutzmer J, Pfänder J (2011) Mineralogy, geochemistry and age of greisen mineralization in the Li-Rb-Cs-Sn-W deposit Zinnwald, Erzgebirge, Germany. Mineral Mag 75 (Suppl): 1833

Steiger RH, JäGER E (1977) Subcommission on Geochronology; convention on the use of decay constants in geoand cosmochronology. Earth Planet Sci Lett 36: 359-362 ŠTEMPROK M (2016) Drill core CS-1 penetrating the Cínoved/ Zinnwald granite cupola (Czech Republic): a review of 
A-type granite magmatic emplacement and important hydrothermal mineralization. J Geosci 61: 395-423

ŠTeMPRoK M, Blecha V (2015) Variscan Sn-W-Mo metallogeny in the gravity picture of the Krušné hory/Erzgebirge granite batholith (Central Europe). Ore Geol Rev 69: 285-300

ŠTeMProk M, Holub FV, NovÁk JK (2003) Multiple magmatic pulses of the Eastern Volcano-Plutonic Complex, Krušné hory/Erzgebirge Batholith, and their phosphorus contents. Bull Geosci 78: 277-296

TAYLOR SR, McLennan SM (1995) The geochemical evolution of the continental crust. Rev Geophys 33: 241-265

Timmerman MJ (2008) Paleozoic magmatism. In: McCanN $\mathrm{T}$ (ed) The Geology of Central Europe Volume 1: Precambrian and Paleozoic. Geological Society of London, pp 665-748

Ulrych J, Fediuk F, Lang M, Martinec P (2004) Late Paleozoic volcanic rocks of the Intra-Sudetic Basin, Bohemian Massif: petrological and geochemical characteristics. Chem Erde 64: 127-153
Weinlich F (1979) Spezielle Inkohlungsuntersuchungen an organischen Substanzen bzw. Kohlen an ausgewählten Proben aus dem Süden der DDR, Bestimmung von Metamorphosenkriterien. Seminar paper, Bergakademie Freiberg, pp 1-40

Wetzel H-U (1984) Spätvariszische Bruchtektonik und subsequente Gangmagmatite als Ausdruck der Krustenentwicklung im Osterzgebirge (Altenberger Scholle). Unpublished PhD thesis, Zentralinstitut für die Physik der Erde, Potsdam, pp 1-230

Winter C, Breitkreuz C, Lapp M (2008) Textural analysis of a Late Palaeozoic coherent to pyroclastic rhyolitic dyke system near Burkersdorf (Erzgebirge, Saxony, Germany). In: Thomson K, PetFord N (eds) Structure and Emplacement of High-Level Magmatic Systems. Geological Society, London, Special Publications 302: 197-219

WoLF L (1960) Ergebnisse einiger Bohrungen im Gebiet des Steinkohlenvorkommens Schönfeld (Osterzgebirge). Z Angew Geol 7: 341-344 